\title{
36. CENOZOIC SILICOFLAGELLATE AND COCCOLITH STRATIGRAPHY, NORTHWESTERN ATLANTIC OCEAN, DEEP SEA DRILLING PROJECT LEG 43
}

\author{
David Bukry, United States Geological Survey, La Jolla, California
}

\section{INTRODUCTION}

Leg 43 of the Deep Sea Drilling Project, which began at Istanbul, Turkey, June 1975, and ended at Norfolk, U.S.A., August 1975, recovered 189 cores at six drilling sites, 382-387 (Figure 1). Light-microscope techniques were used to study the Cenozoic silicoflagellates and coccoliths of 140 samples from these cores. Coccolith zonation of the samples, summarized in Figure 2, follows Bukry (1973c; 1975b). Silicoflagellate zonation is explained in text.

For only the second time, upper Paleocene silicoflagellates are described from DSDP cores; these occur at Site 384. Previously reported occurrences of silicoflagellates at DSDP sites from various oceans are summarized according to their stratigraphic assignment (Tables 1 to 3 ). Several new taxa of silicoflagellates are described from Leg 43 cores: Dictyocha deflandrei lobata, n. subsp.; Mesocena apiculata inflata, n. subsp.; M.? connudata, n. sp.; M. ovata, n. sp.; and Naviculopsis eobiapiculata, n. sp. A new species of the genus incertae sedis Rocella, Rocella schraderi, is described. The genus Rocella can probably be referred to the diatoms because of its pillbox-shaped valves and its occurrence in double-valve sets (frustules).

\section{SITE SUMMARIES}

\section{SITE 382}

(lat $34^{\circ} 25.04^{\prime} \mathrm{N}$, long $56^{\circ} 32.25^{\prime} \mathrm{W}$, depth $5526 \mathrm{~m}$ )

Site 382 is located on Nashville Seamount at the southeasternmost end of the New England Seamount Chain in the northeastern Atlantic Ocean. Coring was intended to date the duration of volcanism and the age of oceanic basement. Cenozoic coccolith-bearing sediments were recovered from Cores 1 to 5 ( 51 to $241 \mathrm{~m}$ ). These sparse to common assemblages are of Quaternary age, moderately etched, and contain common reworked Cretaceous specimens. Samples from the lower part of Core 5 through Core 9 were examined and found to be barren. These samples include: 382 $5-4,120-121 \mathrm{~cm} ; 382-6-3,100-101 \mathrm{~cm} ; 382-7-1,100-$ $101 \mathrm{~cm} ; 382-7-3,110-111 \mathrm{~cm} ; 382-8-2,100-101 \mathrm{~cm}$; $382-8-6,56-57 \mathrm{~cm}$; and 382-9-3, 100-101 cm.

Emiliania annula and E. ovata (syn. Pseudoemiliania lacunosa of Gartner) occur in Cores 2 and 5, but are lacking in Core 1, Section 2. This indicates Cores 2 to 5 are older than 275,000 years (Gartner, 1972). The oldest coccolith assemblage from Core 5 , Section 2 , has a few specimens of Cyclococcolithina sp. cf. C. macintyrei, lacks Gephyrocapsa and Cretaceous reworking, and is assigned to the basal Quaternary Emiliania annula Subzone.

\section{SITE 383}

(lat $39^{\circ} 14.88$ ' $\mathrm{N}$, long $53^{\circ} 21.18$ ' W, depth $5277 \mathrm{~m}$ )

No samples available; see reports of shipboard scientists.

\section{SITE 384 \\ (lat $40^{\circ} 21.65^{\prime} \mathrm{N}$, long $51^{\circ} 39.80^{\prime} \mathrm{W}$, depth $3910 \mathrm{~m}$ )}

Site 384 , on the $J$-anomaly ridge south of Grand Banks, was cored to establish the age of the highamplitude magnetic anomaly and the nature of basement. Coring began at 51 meters subbottom in middle Eocene coccolith ooze; the underlying Cenozoic section that extends to 165 meters was continuously cored in Cores 1 to 12 . Coccoliths are abundant, diverse, and well preserved, only slightly to moderately etched. Silicoflagellates are common and well preserved in the upper Paleocene strata of Cores 6 and 7 ( 99 to $108 \mathrm{~m}$ ).

The Discoaster/Chiasmolithus ratios (Bukry, 1973a) in the middle Eocene Nannotetrina quadrata Zone of Cores 1 to 4 show a warming trend in progressively younger levels, similar to that at more southerly Site 386. Ratios for three representative samples at Site 384 are $66 / 34$ for $384-1-1,110-111 \mathrm{~cm}(52 \mathrm{~m}) ; 55 / 45$ for $384-3-1$, $94-95 \mathrm{~cm}(71 \mathrm{~m})$; and $38 / 62$ for $384-4-2$, $105-106 \mathrm{~cm}(82 \mathrm{~m})$.

Chiasmolithus solitus is abundant in the very diverse lower Eocene assemblage from 384-5-1, 110-111 cm $(90 \mathrm{~m})$. On the presence of a few specimens of Discoaster sp. cf. D. sublodoensis, the assemblage is provisionally assigned to the Discoasteroides kuepperi Subzone. Species present include: Campylosphaera dela, Chiasmolithus grandis, C. solitus, Chiphragmalithus calathus, Coccolithus eopelagicus, C. formosus, Cyclicargolithus pseudogammation, Cyclococcolithina gammation, Cyclolithella? bramlettei, Discoaster barbadiensis, $D$. sp. cf. $D$. deflandrei, $D$. sp. cf. $D$. lodoensis (small), D. mirus, D. sp. cf. D. sublodoensis, Ellipsolithus lajollaensis, Helicosphaera lophota, Lophodolithus mochlophorus, Reticulofenestra dictyoda, Sphenolithus radians, S. spiniger, Striatococcolithus pacificus, Triquetrorhabdulus inversus, Zygolithus dubius, and $Z y$ grhablithus bijugatus.

The Discoaster lodoensis Zone assemblage of 384$5-3,94-95 \mathrm{~cm}(93 \mathrm{~m})$ has abundant Zygrhablithus bijugatus, which is thought to indicate cool conditions (Bukry, 1972; Worsley and Jorgens, 1974). Other characteristic members of the assemblage include 


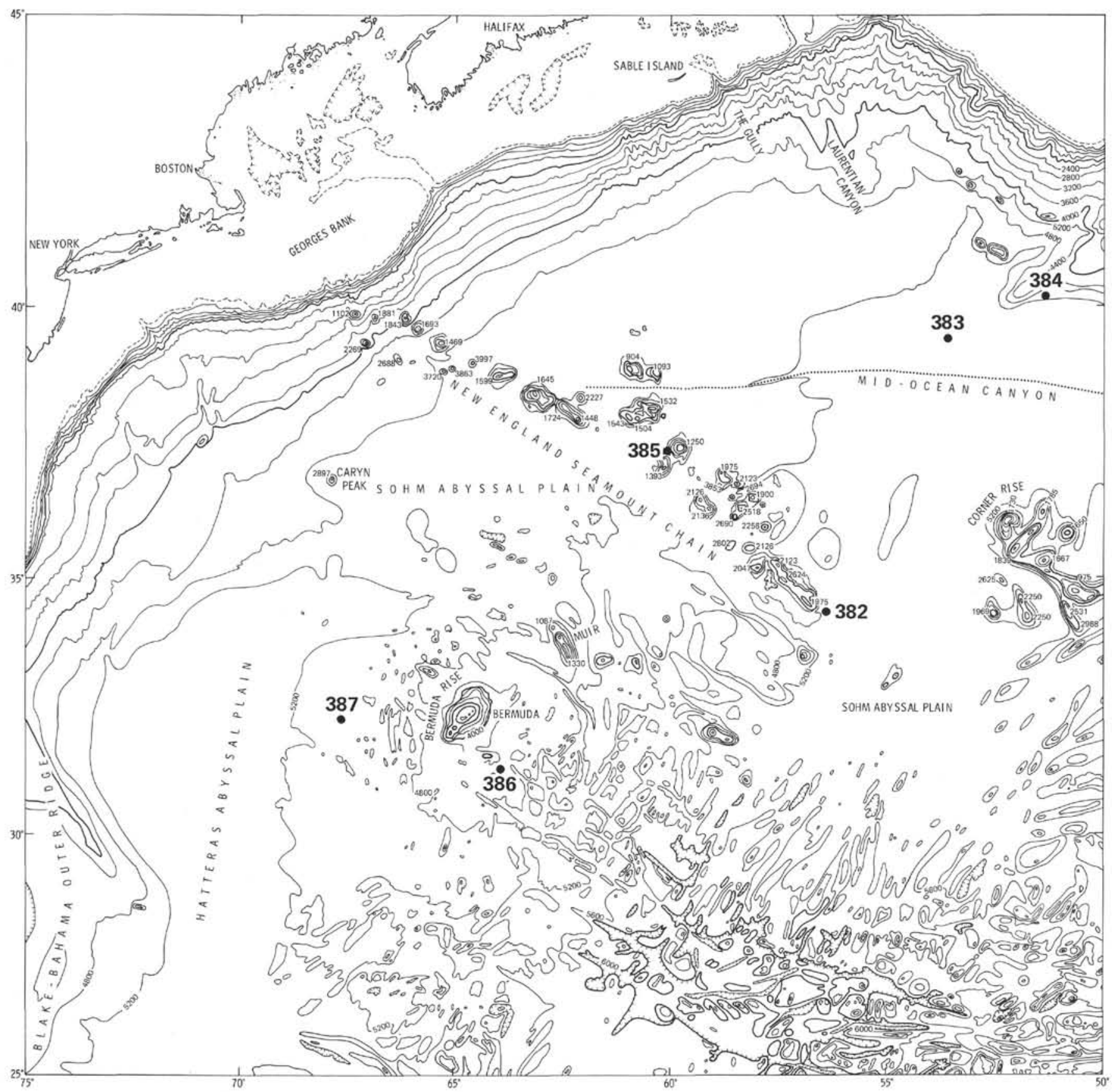

Figure 1. Locations of sites cored by DSDP Leg 43 in the northwestern Atlantic Ocean.

Campylosphaera dela, Chiasmolithus grandis, Coccolithus crassus, C. cribellum, C. formosus, C. magnicrassus, Discoaster barbadiensis, D. cruciformis, D. gemmeus s. str., D. lodoensis, Discoasteroides kuepperi, and Sphenolithus radians. Samples from Core 6 are much older than samples from Core 5. They are late Paleocene and represent a quite different facies where silicoflagellates and diatoms are common. This indicates a diagenetic or sedimentologic break of approximately 4 million years in the section, including the Paleocene-Eocene boundary. Low sedimentation rates and 4.5 -meter void at the base of Core 5 might suggest a possibly continuous section; however, the low sedi- mentation rate seems incompatible with the biogenicrich sediment and cherts reported from the Core 5 core-catcher sample.

Cores 6 and 7 provide a rare opportunity to compare intergroup zonal relations because so many microfossil groups are present. Coccoliths belong to the Discoaster multiradiatus Zone, Discoaster nobilis Zone, and Discoaster mohleri Zone; silicoflagellates belong to the Naviculopsis constricta Zone. Also present are diatoms, foraminifers, and radiolarians. The silicoflagellate assemblage (Figure 3 ) is distinctive in the great abundance of Naviculopsis danica ( $29 \%$ to $78 \%$ ), which is rare in coeval samples from the South Atlantic. 
CENOZOIC SILICOFLAGELLATE AND COCCOLITH STRATIGRAPHY

\begin{tabular}{|c|c|c|c|c|c|c|c|}
\hline Age & Zone & Subzone & 382 & 384 & 385 & 386 & 387 \\
\hline \multirow{5}{*}{$\begin{array}{l}\text { 䓌 } \\
\text { 总 } \\
\text { 岂 }\end{array}$} & Emiliania huxleyi & & \multirow[b]{2}{*}{$1-2$} & & \multirow[b]{2}{*}{$1-1$} & \multirow[b]{2}{*}{$1-2$} & \\
\hline & \multirow{2}{*}{$\begin{array}{c}\text { Gephyrocapsa } \\
\text { oceanica }\end{array}$} & Ceratolithus cristatus & & & & & $1-1$ \\
\hline & & Emiliania ovata & $2-2$ & & & & \\
\hline & \multirow{2}{*}{\begin{tabular}{|l|}
$\begin{array}{c}\text { Crenalithus } \\
\text { doronicoides }\end{array}$ \\
\end{tabular}} & Gephyrocapsa caribbeanica & $3-2 / 4-1$ & & & 14 & \\
\hline & & Emiliania annula & $5-2$ & & & & \\
\hline \multirow{8}{*}{$\begin{array}{l}\text { ֻूँ } \\
\stackrel{\Xi}{2}\end{array}$} & \multirow{4}{*}{$\begin{array}{l}\text { Discoaster } \\
\quad \text { brouweri }\end{array}$} & Cyclococcolithina macintyrei & & & & & \\
\hline & & Discoaster pentaradiatus & & & & & \\
\hline & & Discoaster surculus & & & & & \\
\hline & & Discoaster tamalis & & & & & \\
\hline & \multirow{2}{*}{$\begin{array}{l}\text { Reticulofenestra } \\
\text { pseudoumbilica }\end{array}$} & Discoaster asymmetricus & & & & & \\
\hline & & Sphenolithus neoabies & & & & & \\
\hline & \multirow{3}{*}{$\begin{array}{l}\text { Amaurolithus } \\
\text { tricorniculatus }\end{array}$} & Ceratolithus rugosus & & & & & \\
\hline & & Ceratolithus acutus & & & & & \\
\hline \multirow{15}{*}{ 苋 } & & Triquetrorhabdulus rugosus & & & & & \\
\hline & \multirow{2}{*}{$\begin{array}{l}\text { Discoaster } \\
\quad \text { quinqueramus }\end{array}$} & Amaurolithus primus & & & & & \\
\hline & & Discoaster berggrenii & & & & & \\
\hline & \multirow{2}{*}{$\begin{array}{l}\text { Discoaster } \\
\quad \text { neohamatus }\end{array}$} & Discoaster neorectus & & & & & \\
\hline & & Discoaster bellus & & & & & \\
\hline & \multirow{2}{*}{$\begin{array}{l}\text { Discoaster } \\
\text { hamatus } \\
\end{array}$} & Catinaster calyculus & & & & & \\
\hline & & Helicosphaera carteri & & & & & \\
\hline & \multicolumn{2}{|l|}{ Catinaster coalitus } & & & & & \\
\hline & \multirow{2}{*}{$\begin{array}{c}\text { Discoaster } \\
\text { exilis }\end{array}$} & Discoaster kugleri & & & & & \\
\hline & & Coccolithus miopelagicus & & & & & \\
\hline & Sphenolithus heteromorphus & & & & & & \\
\hline & Helicosphaera ampliaperta & & & & & & \\
\hline & Sphenolithus belemnos & & & & & & \\
\hline & & Discoaster druggii & & & & & \\
\hline & $\begin{array}{l}\text { Triquetrorhabdulus } \\
\text { carinatus }\end{array}$ & Discoaster deflandrei & & & & & \\
\hline & & Cyclicargolithus abisectus & & & & & \\
\hline & Sphenolithus & Dictyococcites bisectus & & & & $4-5$ & \\
\hline \& & ciperoensis & Cyclicargolithus floridanus & & & & & \\
\hline 8 & Sphenolithus distentus & & & & & $5-3$ & \\
\hline$\ddot{\circ}$ & Sphenolithus predistentus & & & & & ?6-3/9-3 & \\
\hline & & Reticulofenestra hillae & & & & & \\
\hline & $\begin{array}{l}\text { Helicosphaera } \\
\text { reticulata }\end{array}$ & Coccolithus formosus & & & & $11-3$ & \\
\hline & & Coccolithus subdistichus & & & & & \\
\hline & Discoaster & Isthmolithus recurvus & & & & $12-4$ & \\
\hline & barbadiensis & Chiasmolithus oamaruensis & & & & & \\
\hline & Reticulofenestra & Discoaster saipanensis & & & & & \\
\hline & umbilica & Discoaster bifax & & & & $14-1 / 14-3$ & \\
\hline & & Coccolithus staurion & & & & $14-5$ & \\
\hline ङूँ & $\begin{array}{l}\text { Nannotetrina } \\
\text { quadrata }\end{array}$ & Chiasmolithus gigas & & $1-1 / 3-1$ & & $15-1 / 17-1$ & $9-1 / 13-1$ \\
\hline : & & Discoaster strictus & & $4-2 / 4-5$ & & 18-1 & $16-2 / ? 17-2$ \\
\hline & Discoaster & Rhabdosphaera inflata & & & & $23-3 / 26-2{ }^{19-3 / 22-4}$ & $18-1 / 19-2$ \\
\hline & sublodoensis & Discoasteroides kuepperi & & $? 5-1$ & & & \\
\hline & Discoaster lodoensis & & & $5-3$ & & $27-4 / 31-2$ & $20-2 / 21-2$ \\
\hline & Tribrachiatus orthostylus & & & & & $32-4 / 33-1$ & $22-2 / 23-1$ \\
\hline & Discoaster & Discoaster binodosus & & & & $33-3$ & \\
\hline & diastypus & Tribrachiatus contortus & & & & & \\
\hline & Discoaster & Campylosphaera eodela & & & & $34-2$ & $? 23-5$ \\
\hline & multiradiatus & Chiasmolithus bidens & & $6-1$ & & $34-4$ & \\
\hline हूँ & Discoaster nobilis & & & $6-1 / 6-3$ & & & \\
\hline ¿ूँ & Discoaster mohleri & & & $6-4 / 8-3$ & & & \\
\hline 2 & Heliolithus kleinpellii & & & & & & \\
\hline & Fasciculithus tympaniformis & & & $9-3$ & & & \\
\hline & Cruciplacolithus tenuis & & & $10-3 / 12-3$ & $11-2$ & & $24-1 / 26-1$ \\
\hline
\end{tabular}

Figure 2. Cenozoic coccolith zonation of core samples from sites of Deep Sea Drilling Project Leg 43. The numbers assigned to zonal intervals are core and section numbers of samples examined. Where a zone or subzone is represented in samples from two or more core sections, the highest and lowest are given. 
TABLE 1

Summary of Atlantic Ocean and

Mediterranean Sea Deep Sea Drilling

Project Sites (6 to 386) for Which Silicoflagellates are Reported

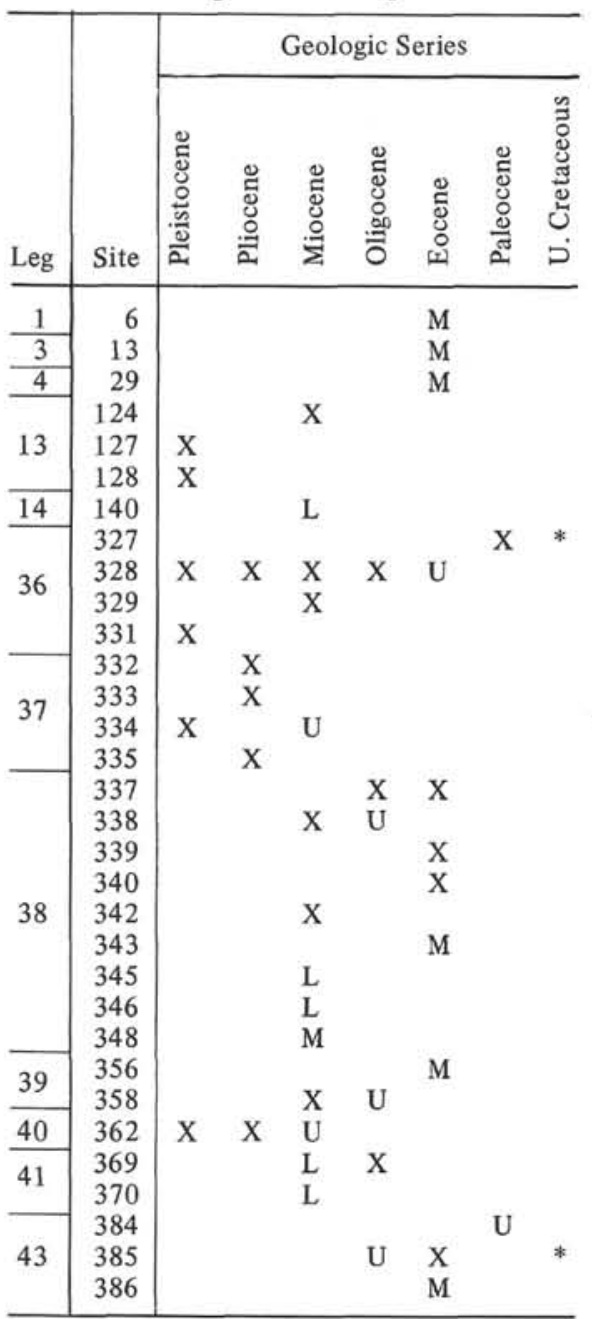

Note: Report sources published outside the Initial Reports of the Deep Sea Drilling Project for Sites 6 and 13 (Ling, 1972) and Sites 6, 13, 29, and 140 (Bukry and Foster, 1974). $X=$ Present; $U, M$, or $L=$ Subseries Designated; $*=$ Present as Reworked Specimens.

Another unusual feature of the assemblage is the sparse but persistent occurrence of Corbisema sp. cf. $C$. hastata hastata having short, paired spines in the manner of $C$. bimucronata bimucronata. Coccolith assemblages are diverse and include species that typically are uncommon in deep ocean locales, such as Ellipsolithus distichus, Heliolithus riedelii, and Sphenolithus anarrhopus. Discoaster nobilis, in Core 6, is represented by typical specimens and by compared specimens of four to seven rays that have exceptionally long but uncurved rays. These compared specimens also occur below the range of $D$. nobilis s. str. in Samples 6-4, CC, and 7-1.

The youngest Paleocene sample available, 384-6-1, $49-51 \mathrm{~cm}(99 \mathrm{~m})$, contains abundant Discoaster multi-
TABLE 2

Summary of Indian Ocean Deep Sea

Drilling Project Sites (211 to 253) for

Which Silicoflagellates are Reported

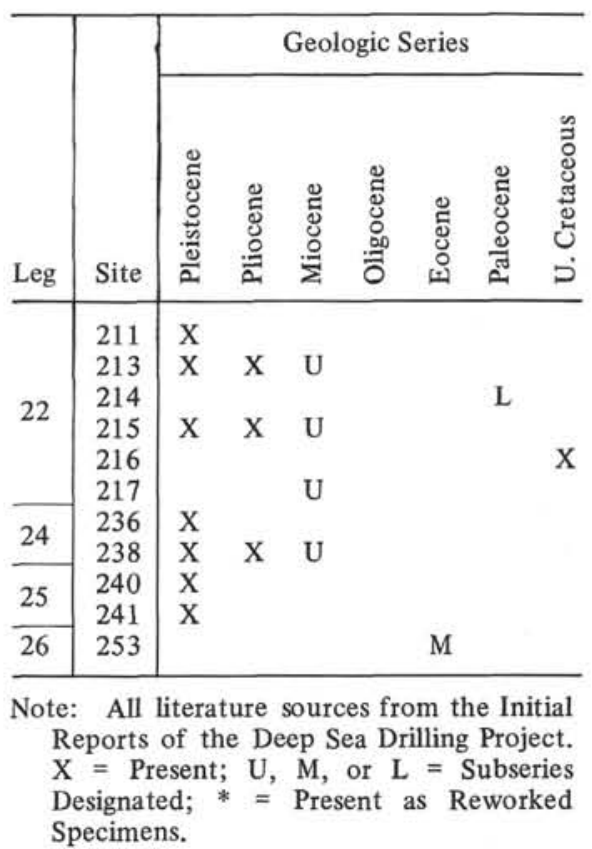

radiatus and fasciculiths, such as Fasciculithus clinata, $F$. hayi, and $F$. tympaniformis, but lacks Campylosphaera or Rhomboaster and is assigned to the Chiasmolithus bidens Subzone. This is the only sample available from Core 6 that contains $D$. multiradiatus and the only sample that lacks silicoflagellates; diatoms are more solution thinned than below. The next deeper Paleocene sample available, 384-6-1, 100-101 cm (100 $\mathrm{m}$ ), contains Discoaster mohleri, D. nobilis, D. sp. cf. $D$. nobilis, and Discoasteroides megastypus, and common silicoflagellates.

Lower Paleocene Cruciplacolithus tenuis Zone assemblages in Cores 10 to 12 (136 to $165 \mathrm{~m}$ ) are characterized by Coccolithus pelagicus s. ampl., $Z y$ godiscus sigmoides, and Cruciplacolithus tenuis which becomes larger toward the top of the interval. The highest sample examined, 384-10-3, 120-121 cm (140 $\mathrm{m}$ ), also contains Braarudosphaera bigelowii, Chiasmolithus sp. cf. C. bidens, Ellipsolithus sp. cf. E. distichus, Heliorthus distentus, and Thoracosphaera operculata.

\section{SITE 385}

(lat $37^{\circ} 22.17^{\prime} \mathrm{N}$, long $60^{\circ} 09.45^{\prime} \mathrm{W}$, depth $4956 \mathrm{~m}$ )

Site 385 , located on Vogel Seamount in the New England Seamount Chain, was cored to test platetectonic hot-spot theory by comparing its age to Nashville Seamount (Site 382). Cenozoic sediment was recovered in Cores 1 to 11 ( 22 to $213 \mathrm{~m}$ ); only Cores 4 to 11 were continuously cored ( 137 to $213 \mathrm{~m}$ ). Several different facies and ages of sediment containing coccoliths or silicoflagellates are present.

A late Quaternary Emiliania huxleyi Zone(?) coccolith ooze containing abundant small placoliths (Emiliania huxleyi?) and Gephyrocapsa oceanica at the top of 
TABLE 3

Summary of Pacific Ocean and Antarctic Area Deep Sea Drilling Project Sites (32 to 323) for Which Silicoflagellates are Reported

\begin{tabular}{|c|c|c|c|c|c|c|c|c|}
\hline \multirow[b]{2}{*}{ Leg } & \multirow[b]{2}{*}{ Site } & \multicolumn{7}{|c|}{ Geologic Series } \\
\hline & & 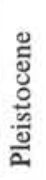 & $\begin{array}{l}\stackrel{0}{8} \\
\stackrel{\Xi}{0} \\
\end{array}$ & 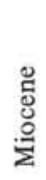 & 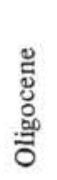 & 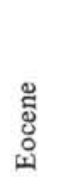 & 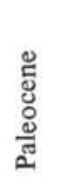 & 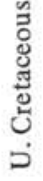 \\
\hline \multirow{3}{*}{5} & 32 & $\mathrm{X}$ & $\mathrm{X}$ & $\mathrm{X}$ & & & & \\
\hline & 33 & $\mathrm{X}$ & $\mathrm{X}$ & $\mathrm{X}$ & & & & \\
\hline & 34 & & & $\mathrm{X}$ & & & & \\
\hline \multirow[t]{3}{*}{7} & $\begin{array}{l}65 \\
66\end{array}$ & $\begin{array}{l}X \\
X\end{array}$ & $\begin{array}{l}X \\
X\end{array}$ & $\mathrm{X}$ & & & & \\
\hline & 77 & $\mathrm{X}$ & $\mathrm{X}$ & $\mathrm{X}$ & & & & \\
\hline & 79 & $\mathrm{X}$ & $\mathrm{X}$ & $U$ & & & & \\
\hline \multirow{5}{*}{9} & 80 & $\mathrm{X}$ & $\mathrm{X}$ & $\mathrm{X}$ & & & & \\
\hline & 81 & $\mathrm{X}$ & & M & & & & \\
\hline & 82 & $\mathrm{X}$ & $\mathrm{X}$ & $\mathrm{U}$ & & & & \\
\hline & 83 & $\mathrm{X}$ & $\mathrm{X}$ & $\mathrm{X}$ & & & & \\
\hline & 84 & $\mathrm{X}$ & $\mathrm{X}$ & $\mathrm{U}$ & & & & \\
\hline \multirow{2}{*}{16} & 157 & $\mathrm{x}$ & $\mathrm{X}$ & $\mathrm{U}$ & & & & \\
\hline & 158 & & & $\mathrm{X}$ & & & & \\
\hline 17 & 166 & & $\mathrm{X}$ & $\mathrm{X}$ & $\mathrm{X}$ & $\mathrm{U}$ & & \\
\hline \multirow{4}{*}{18} & 173 & $\mathrm{X}$ & $\mathrm{X}$ & $\mathrm{X}$ & & & & \\
\hline & 183 & $\mathrm{X}$ & $\mathrm{X}$ & $\mathrm{U}$ & & & & \\
\hline & 184 & $X$ & $\mathrm{X}$ & $\mathrm{U}$ & & & & \\
\hline & 185 & $\mathrm{X}$ & $\mathrm{X}$ & $\mathrm{X}$ & & & & \\
\hline \multirow{7}{*}{19} & 186 & $\mathrm{X}$ & $\mathrm{X}$ & $\mathrm{X}$ & & & & \\
\hline & 187 & $\mathrm{X}$ & $\mathrm{X}$ & & & & & \\
\hline & 188 & $\mathrm{X}$ & $\mathrm{X}$ & $\mathrm{U}$ & & & & \\
\hline & 189 & $\mathrm{X}$ & $\mathrm{X}$ & & & & & \\
\hline & 190 & $\mathrm{X}$ & $\mathrm{X}$ & U & & & & \\
\hline & 191 & $\mathrm{X}$ & $\mathrm{X}$ & & & & & \\
\hline & 192 & $\mathrm{X}$ & & $\mathrm{X}$ & & & & \\
\hline \multirow[t]{3}{*}{20} & 194 & $\mathrm{X}$ & & & & & & \\
\hline & $\begin{array}{l}195 \\
203\end{array}$ & $x$ & $\mathrm{X}$ & & & & & \\
\hline & 205 & & & $\mathrm{U}$ & & & & \\
\hline \multirow[t]{6}{*}{21} & 206 & $\mathrm{X}$ & $\mathrm{X}$ & $\mathrm{X}$ & $\mathrm{X}$ & M & & \\
\hline & 207 & & & & & $\mathrm{M}$ & & \\
\hline & 208 & & & & & M & L & \\
\hline & 264 & & & & & $X$ & & \\
\hline & 265 & & $\mathrm{X}$ & $\mathrm{X}$ & & & & \\
\hline & 266 & $\mathrm{X}$ & $\mathrm{X}$ & $\mathrm{X}$ & $\mathrm{U}$ & & & \\
\hline \multirow{7}{*}{28} & 267 & $\mathrm{X}$ & $\mathrm{X}$ & & $\mathrm{x}$ & & & \\
\hline & 269 & $\mathrm{X}$ & $\mathrm{X}$ & & & & & \\
\hline & 271 & $\mathrm{X}$ & $\mathrm{X}$ & & & & & \\
\hline & 272 & $\mathrm{X}$ & & & & & & \\
\hline & 274 & $\mathrm{X}$ & $X$ & $\mathrm{U}$ & $\mathrm{X}$ & & & \\
\hline & 275 & & & & & & & $\mathrm{X}$ \\
\hline & 277 & & & & $\mathrm{X}$ & $\mathrm{X}$ & & \\
\hline \multirow[t]{5}{*}{29} & 278 & $\mathrm{X}$ & $\mathrm{X}$ & $\mathrm{X}$ & $\mathrm{U}$ & & & \\
\hline & 280 & & & & $\mathrm{X}$ & & & \\
\hline & 281 & $\mathrm{X}$ & & $\mathrm{X}$ & & $\mathrm{X}$ & & \\
\hline & 283 & & & & & $X$ & & \\
\hline & 285 & & & $\mathrm{X}$ & & & & \\
\hline \multirow[t]{3}{*}{30} & 286 & $\mathrm{X}$ & & & & & & \\
\hline & 288 & $\mathrm{X}$ & & & & & & \\
\hline & 298 & $\mathrm{X}$ & & & & & & \\
\hline \multirow[t]{3}{*}{31} & 299 & $X$ & U & & & & & \\
\hline & 301 & $\mathrm{X}$ & $\begin{array}{l}X \\
X\end{array}$ & $\begin{array}{l}\mathrm{U} \\
\mathrm{U}\end{array}$ & & & & \\
\hline & $\begin{array}{l}302 \\
303\end{array}$ & $\begin{array}{l}X \\
X\end{array}$ & $\begin{array}{l}X \\
\mathrm{~L}\end{array}$ & $\mathrm{X}$ & & & & \\
\hline \multirow[t]{2}{*}{32} & 304 & & L & $\mathrm{X}$ & & & & \\
\hline & 310 & $\mathrm{X}$ & $\mathrm{X}$ & $\mathrm{U}$ & & & & \\
\hline
\end{tabular}

TABLE 3 - Continued

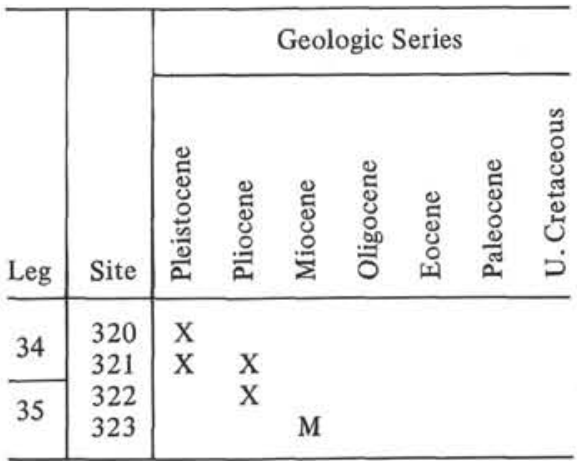

Note: All literature sources from the Initial Reports of the Deep Sea Drilling Project and from Bukry and Foster (1974) for Sites 206, 208, 214, 216, and 275. X = Present; U, M, or L = Subseries Designated; * = Present as Reworked Specimens.

Core 1 ( 22 to $32 \mathrm{~m}$ ) probably represents an in-hole slump of surficial material, as manganese nodules, which are most common in surface sediments, are reported. The only other available coccolith-bearing sample from the Cenozoic is Sample 385-11-2, 140-141 $\mathrm{cm}(205 \mathrm{~m})$, from the basal Cruciplacolithus tenuis Zone of early Paleocene age. Reworked Cretaceous or indigenous basal Paleocene species are difficult to distinguish in this strongly etched assemblage. Species present include: Biantholithus sparsus, Biscutum testudinarium, Cruciplacolithus sp. cf. C. tenuis, Eiffellithus turriseiffeli, Markalius inversus, Micula decussata, $M$. mura, Prediscosphaera cretacea, Thoracosphaera operculata, Watznaueria sp. cf. W. barnesae (circular), $Z$ ygodiscus sigmoides, and $Z$. spiralis.

Sparse silicoflagellate assemblages of probable late Oligocene age are present in Cores 2 and 3 (60 to 108 $\mathrm{m})$. Middle or possibly early Eocene assemblages in Cores 4 and 6 (137 to $165 \mathrm{~m}$ ) are more abundant. Samples from Core 2 contain less-etched specimens than Core 3. The occurrence of Mesocena apiculata apiculata, Naviculopsis biapiculata (rare), N. eobiapiculata, and the probable diatoms Rocella gelida and $R$. schraderi (see Genera Incertae Sedis Taxonomy) suggests the late Oligocene Naviculopsis biapiculata Zone (Figure 4). The assemblages are, however, sparse, etched, and contain reworked Cretaceous silicoflagellates. Dissolution is pervasive in Core 3 , as evident in the reduced diversity and physical state of Rocella gelida, which has had most of its margins dissolved. In Core 2, margins are intact and even double valve sets are preserved.

Eocene silicoflagellates of the Dictyocha spinosa Subzone in Cores 4 and 6 are dominated by Corbisema triacantha triacantha, Dictyocha deflandrei lobata, Naviculopsis constricta, and $N$. foliacea (Figure 5). Dictyocha spinosa occurs in all samples and $D$. hexacantha is absent. A similar but slightly younger assemblage of the same subzone occurs at Site 386, where associated coccoliths belong to the middle Eocene 


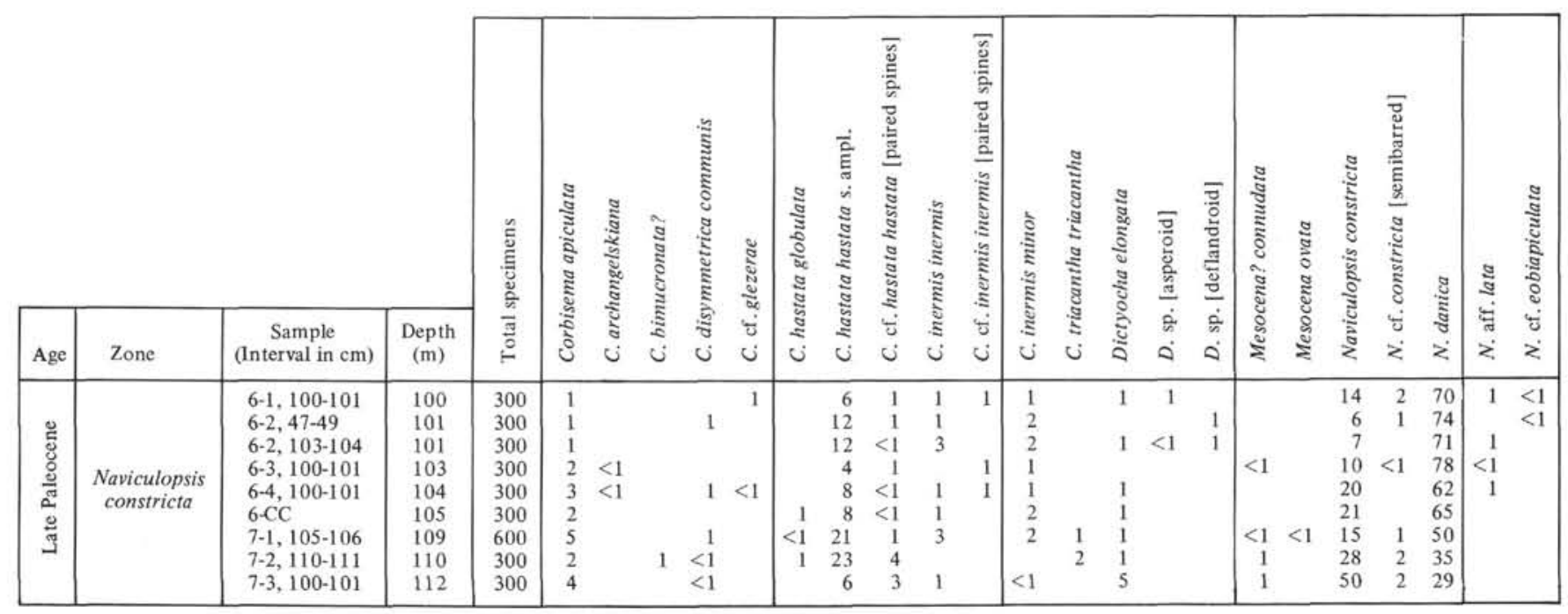

Figure 3. Occurrence of late Paleocene silicoflagellates in Cores 6 and 7 at Site 384 recorded as per cent of total number of specimens counted.

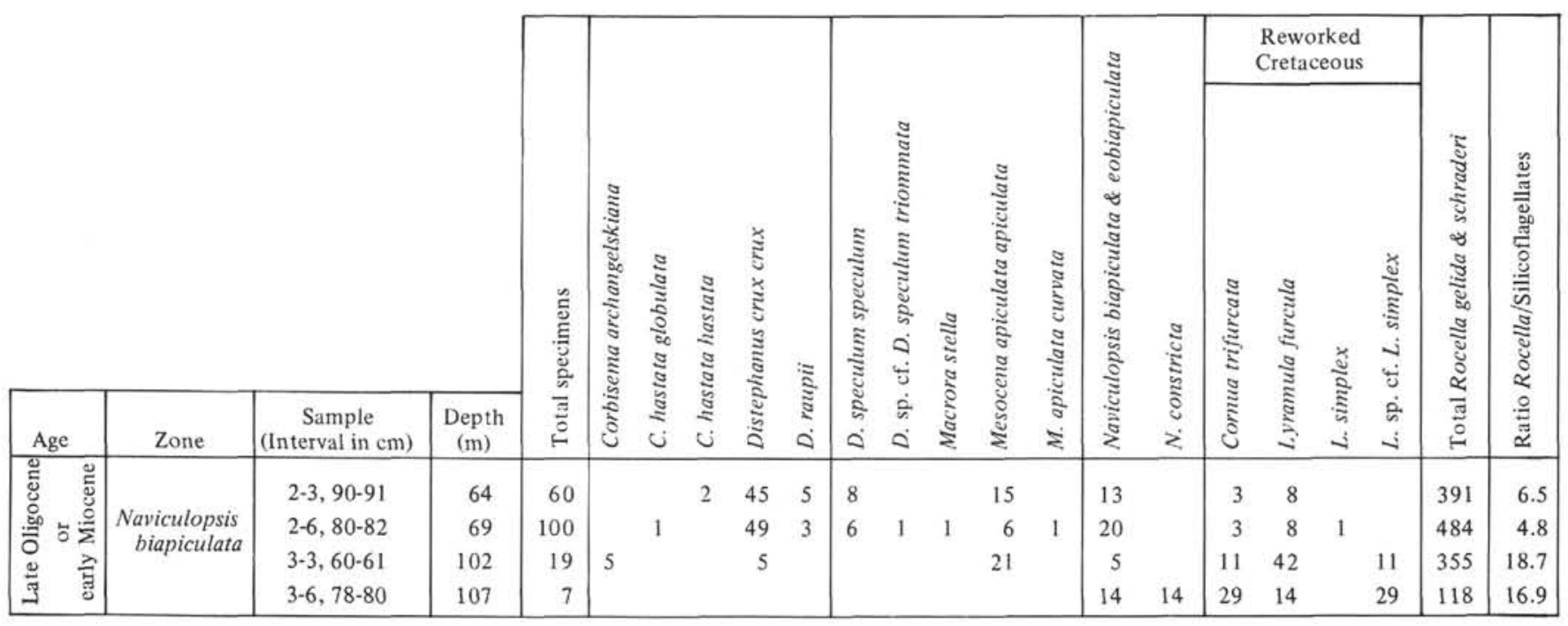

Figure 4. Occurrence of silicoflagellates and diatom(?) Rocella in Cores 2 and 3 at Site 385 recorded as per cent of total number of specimens counted. Silicoflagellates are rare relative to the solution-resistant genus Rocella. Assemblages of Core 3 show intense solution because reworked silicoflagellates dominate and Rocella is present mainly as central-area fragments. Indigenous silicoflagellates are sparse, as they should be less solution resistant than diatoms according to laboratory dissolution experiments (Naja Mikkelsen, oral communication, 1976).

Chiasmolithus gigas Subzone. Several distinctive diatom species at the two sites also suggest similar ages.

\section{SITE 386}

(lat $31^{\circ} 11.21^{\prime} \mathrm{N}$, long $64^{\circ} 14.94^{\prime} \mathrm{W}$, depth $4783 \mathrm{~m}$ )

Site 386 , located south of Bermuda on the central Bermuda Rise, was cored to help establish the age and nature of North Atlantic acoustic reflector Horizon $A$ and the underlying sediment. Cenozoic coccoliths are common to abundant in Cores 1 to 34 ( 53 to $613 \mathrm{~m}$ ). Middle Eocene silicoflagellates are few to common in Cores 14 to 17 ( 328 to $395 \mathrm{~m}$ ) (Figure 6).

Most of the coccolith-bearing section, in Cores 4 to 33, is of Oligocene and Eocene age. Core 1 (53 to 62 m) contains abundant Quaternary coccoliths. The top sample, 386-1-2, 100-101 cm (53 m), may represent an in-hole contamination for the presence of Gephyrocapsa oceanica and the absence of Emiliania annula suggests that it is considerably younger than Sample 386-1-4, 98-99 cm (57 m), which contains Gephyrocapsa caribbeanica and Emiliania annula. Barren clay occurs in Samples 384-1-6, 100-101 cm (62 m), 386$2-1,132-133 \mathrm{~cm}(101 \mathrm{~m})$, and 386-4-1, 115-116 cm (148 m).

With few exceptions, coccoliths are diverse and well preserved in the Oligocene and Eocene, and assemblages of 25 or more species are not uncommon. Part of the diversity of late Oligocene and older samples is 


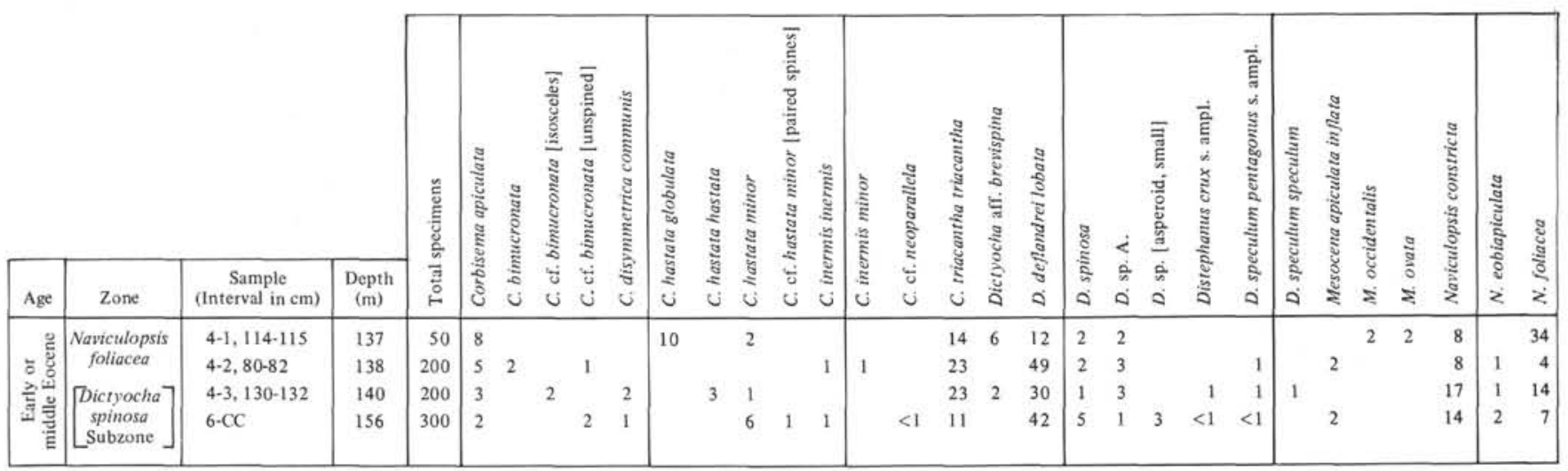

Figure 5. Occurrence of Eocene silicoflagellates in Cores 4 and 6 at Site 385 recorded as per cent of total number of specimens counted.

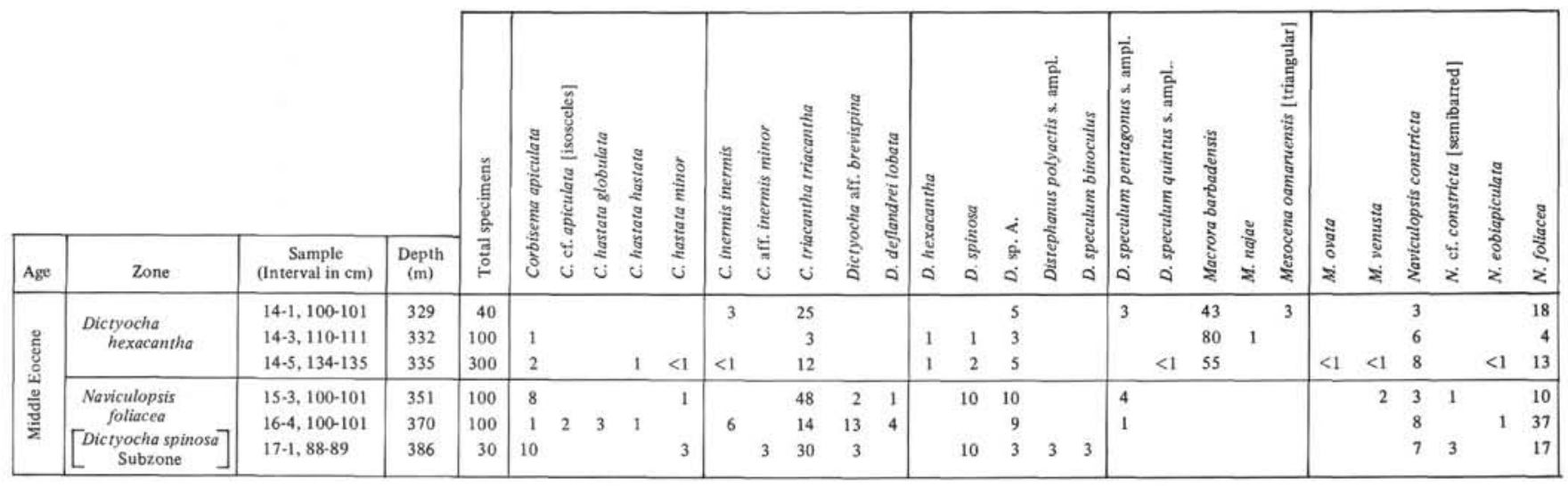

Figure 6. Occurrence of Eocene silicoflagellates in Cores 14 to 17 at Site 386 recorded as per cent of total number of specimens counted.

related to mixing of older and younger species in the volcanoclastic turbidite sediment sequence. For example, Sample $386-4-5,100-101 \mathrm{~cm}(154 \mathrm{~m})$, is assigned to the undivided Sphenolithus ciperoensis Zone, but contains older species such as Sphenolithus pseudoradians and Vermiculithina arca associated with young species such as Sphenolithus capricornutus and $S$. ciperoensis. Other species present in the assemblage include: Braarudosphaera bigelowii, B. rosa, Coccolithus miopelagicus, Cyclicargolithus abisectus, C. floridanus, Dictyococcites bisectus, Discoaster deflandrei, Helicosphaera euphratis, ?Rhabdosphaera tenuis (stems), Sphenolithus dissimilis, S. distentus, S. moriformis, S. predistentus, Triquetrorhabdulus carinatus, and Zygrhablithus bijugatus.

The rich early Oligocene Helicosphaera reticulata Zone assemblage of Sample 386-11-3, 50-51 cm (255 $\mathrm{m})$, contains: Braarudosphaera bigelowii, B. rosa, Chiasmolithus altus, Coccolithus eopelagicus, C. formosus, C. pelagicus, C. sp. cf. C. subdistichus, Cyclicargolithus floridanus, Dictyococcites bisectus, D. scrippsae, Discoaster nodifer, D. tanii, Helicosphaera compacta, H. euphratis, Micrantholithus aequalis, Pedinocyclus larvalis, Quinquerhabdus colossicus, Reticulofenestra hillae, $R$. umbilica, ?Rhabdosphaera tenuis (stems),
Sphenolithus moriformis, and $S$. predistentus (common).

A late Eocene sample, 386-12-4, 100-101 cm (286 $\mathrm{m})$, of the Isthmolithus recurvus Zone contains rare Isthmolithus recurvus. A high Dicoaster/Chiasmolithus ratio indicates relatively warmer conditions than for older middle Eocene assemblages (Figure 7). However, the possibility of minor mixing of assemblages in a turbidite sequence reduces the significance of relative counts. The late Eocene assemblage appears to have little or no mixing. Species present include: Bramletteius serraculoides, Chiasmolithus altus, C. oamaruensis, Coccolithus formosus, C. pelagicus, Cyclicargolithus floridanus, Dictyococcites bisectus, $D$. scrippsae, Discoaster barbadiensis, D. deflandrei, D. sp. cf. D. tanii, Helicosphaera compacta, H. reticulata, Isthmolithus recurvus, Pemma papillatum, Reticulofenestra hillae, $R$. umbilica, ?Rhabdosphaera tenuis (stems), and Sphenolithus moriformis.

Middle Eocene assemblages of Cores 14 to 26 (328 to $490 \mathrm{~m}$ ) contain small numbers of reworked Cretaceous and Paleocene species. Reticulofenestra umbilica populations are not well developed, however the overlaps in ranges of Chiasmolithus solitus and Sphenolithus obtusus in part of Core 14 suggests the lower part 


\begin{tabular}{|c|c|c|l|}
\hline $\begin{array}{c}\text { Site 386 } \\
\text { Sample }\end{array}$ & $\begin{array}{c}\text { Depth } \\
(\mathrm{m})\end{array}$ & $\begin{array}{c}\text { Discoaster/ } \\
\text { Chiasmolithus } \\
\text { Ratio }\end{array}$ & Age \\
\hline $12-4,100-101 \mathrm{~cm}$ & 286 & $87 / 13$ & $\begin{array}{l}\text { Late } \\
\text { Eocene }\end{array}$ \\
\hline $14-1,100-101 \mathrm{~cm}$ & 329 & $61 / 39$ & \\
$14-3,110-111 \mathrm{~cm}$ & 332 & $51 / 49$ & Middle \\
$15-1,109-110 \mathrm{~cm}$ & 348 & $47 / 53$ & Eocene \\
$16-2,88-89 \mathrm{~cm}$ & 367 & $45 / 55$ & \\
$17-1,88-89 \mathrm{~cm}$ & 386 & $39 / 61$ & \\
\hline
\end{tabular}

Figure 7. Slight increase in the Discoaster/ Chiasmolithus ratio (Bukry, 1973a) indicates warming trend through the middle and late Eocene at Site 386. Only rare specimens of cool-water species Chiasmolithus altus and Isthmolithus recurvus occur in section 12-4.

of the Reticulofenestra umbilica Zone. Species present in Sample 386-14-1, 100-101 cm (329 m), include such reworked Cretaceous taxa as Micula decussata and Prediscosphaera cretacea, and the Paleocene species Fasciculithus schaubii. Some species such as Ellipsolithus lajollaensis, Lophodolithus acutus, and Scyphosphaera expansa that are usually associated with lower middle Eocene assemblages are also present and might be reworked. Chiasmolithus gigas, a distinctive middle Eocene marker species (Bukry, 1973c) ranges from Core 17, Section 1, to Core 15, Section 1, but its absence in Sections 3 and 5 of Core 15 could suggest that it is reworked into Section 1. Future study of Core 15 might determine this.

The deepest sample assigned the Nannotetrina quadrata Zone, 386-18-1, 99-100 cm (405 m), belongs to the Discoaster strictus Subzone and contains abundant Chiasmolithus solitus. Other species present include: Chiasmolithus grandis, Coccolithus pelagicus, Cyclicargolithus pseudogammation, Cyclococcolithina? luminis, Discoaster barbadiensis, D. distinctus, D. saipanensis, D. strictus, Helicosphaera seminulum, Lophodolithus rotundus, Nannotetrina alata, Reticulofenestra dictyoda, R. samodurovii, Rhabdosphaera tenuis, Sphenolithus radians, $S$. spiniger, Transversopontis pulcher, and Zygolithus dubius, and reworked Cretaceous Eiffellithus turriseiffeli and Micula decussata.

Coccoliths from limestones and claystones of Cores 19 to 22 (414 to $452 \mathrm{~m}$ ) are poorly diagnostic but are lower middle Eocene, because they are underlain by Rhabdosphaera inflata Subzone assemblages in Cores 23 to 26 (452 to $490 \mathrm{~m}$ ). The most diagnostic assemblage in Sample 386-26-2, 51-52 cm (481 m), includes: Campylosphaera dela, Chiasmolithus solitus, Chiphragmalithus acanthodes, Coccolithus formosus, C. pelagicus, Cyclicargolithus pseudogammation, Cyclococcolithina gammation, Discoaster barbadiensis, D. lodoensis, D. sublodoensis, Discoasteroides kuepperi, Helicosphaera lophota, Lophodolithus nascens, Reticulofenestra dictyoda, Rhabdosphaera inflata, Sphenolithus radians, and Zygolithus dubius, and reworked Cretaceous taxa, Arkhangelskiella cymbiformis, Cribrosphaera ehrenbergii, Micula decussata, and Prediscosphaera cretacea.
Lower Eocene Discoaster lodoensis Zone assemblages contain characteristic species such as Coccolithus crassus and Discoaster lodoensis, and in Samples 386$27-4,117-118 \mathrm{~cm}(495 \mathrm{~m})$, and $386-30-2,86-87 \mathrm{~cm}$ $(520 \mathrm{~m})$, uncharacteristic Reticulofenestra sp. cf. $R$. umbilica. This large species usually appears near the top of the middle Eocene, but in the North Atlantic region it, or a similar form, can occur in the $D$. lodoensis Zone (Perch-Nielsen, 1972).

The uppermost part of the Paleocene is identified in Sample 386-34-2, 71-72 cm (606 m), by the occurrence of Campylosphaera eodela, Discoaster araneus, and Rhomboaster cuspis, indicating the Campylosphaera eodela Subzone. Assemblages of this and the underlying Chiasmolithus bidens Subzone in Sample 386-34-4, $78-79 \mathrm{~cm}(609 \mathrm{~m})$, are moderately etched, but diverse. Species present include Chiasmolithus bidens, C. consuetus, Discoaster multiradiatus, D. nobilis, Ellipsolithus distichus, E. macellus, Fasciculithus sp. cf. F. involutus, F. schaubii, Heliolithus sp. cf. H. kleinpellii, Heliorthus chiastus, $H$. distentus, $H$. junctus, Sphenolithus anarrhopus, Toweius eminens, T. craticulus, Zygodiscus adamas, and $Z$. sigmoides, and reworked Cretaceous taxon Arkhangelskiella cymbiformis.

\section{SITE 387}

\section{(lat $32^{\circ} 19.2^{\prime} \mathrm{N}$, long $67^{\circ} 40^{\prime} \mathrm{W}$, depth $5118 \mathrm{~m}$ )}

Site 387 , located east of Bermuda, was cored to identify the age and composition of important acoustic reflector horizons in the western North Atlantic Ocean. As at other sites drilled during Leg 43, Quaternary coccoliths occur at the top of the section, but the next older coccolith-bearing sediments are of Paleogene age. The abundant late Quaternary coccolith assemblage of Sample 387-1-1, 100-101 cm (32 m), lacks Emiliania annula but contains an abundance of small placoliths, ?Emiliania huxleyi. Other species present indicate a warm-water assemblage: Ceratolithus cristatus, $C$. telesmus, Coccolithus pelagicus, Cyclococcolithina leptopora, Gephyrocapsa oceanica, Helicosphaera carteri, Rhabdosphaera clavigera, Scapholithus sp., and Umbilicosphaera sibogae.

The next youngest coccolith assemblage is the middle Eocene Chiasmolithus gigas Subzone of Sample $387-9-1,110-111 \mathrm{~cm}(195 \mathrm{~m})$, which also contains sparse silicoflagellates and the first occurrence of $\mathrm{Ma}$ crora barbadensis. This first occurrence of $M$. barbadensis in the upper middle Eocene is similar to that observed at other DSDP sites in the Atlantic Ocean such as Sites 386, 356, 29, and 6 (Bukry and Foster, 1974; Bukry, 1977a). The best coccolith assemblage of the $C$. gigas Subzone in Sample 387-10-5, 120-121 cm $(210 \mathrm{~m})$, contains Campylosphaera dela, Chiasmolithus expansus, C. gigas, C. grandis, C. solitus, Coccolithus sp. cf. C. staurion, Discoaster barbadiensis, D. sp. cf. D. distinctus, D. gemmifer, D. nodifer, D. strictus, Lophodolithus acutus, L. rotundus, Nannotetrina alata, Reticulofenestra sp. cf. $R$. dictyoda, $R$. samodurovii, Rhabdosphaera tenuis, Syracosphaera labrosa, Zygolithus dubius, and Zygrhablithus bijugatus. 
Rare specimens of Rhabdosphaera inflata in samples from Cores 18 and 19 (289 to $317 \mathrm{~m}$ ) suggest an early middle Eocene age, although other diagnostic species are lacking in the moderately etched assemblages which contain reworked Cretaceous species.

The occurrence of Coccolithus crassus, $C$. magnicrassus, Discoaster lodoensis, and Helicosphaera lophota in Sample 387-20-2, 87-88 cm (329 m), indicates the lower Eocene Discoaster lodoensis Zone. The Tribrachiatus orthostylus Zone of Cores 22 and 23 (355 to $384 \mathrm{~m}$ ) contains some reworked Paleocene specimens such as Toweius eminens and Zygodiscus sigmoides. Three deeper Paleocene coccolith assemblages, from Cores 23, 24, and 26, are strongly etched and fragmented at preservation stage -4 (Bukry, 1973b). The presence of rare Discoaster multiradiatus and Rhomboaster sp. cf. $R$. cuspis, nearly evolved to Tribrachiatus nunnii in the Tribrachiatus contortus plexus, suggests that Sample $387-23-5,38-39 \mathrm{~cm}(381 \mathrm{~m})$, is uppermost Paleocene. Reworked Cretaceous and $\mathrm{Pa}$ leocene taxa, such as Arkhangelskiella cymbiformis, Heliolithus kleinpellii, and Micula decussata, are present. Sample 387-24-1, 136-137 cm (394 m), contains Chiasmolithus sp. cf. C. danicus and Cruciplacolithus tenuis, indicating the lower part of the Paleocene. The deepest sample available from the Cenozoic, Core 26, contains rare Coccolithus pelagicus s. ampl. and Cruciplacolithus tenuis. Cretaceous taxa dominate in this sample, however. A high proportion of Micula decussata among the Cretaceous taxa helps confirm that the assemblage is a dissolution concentrate.

\section{SILICOFLAGELLATE ZONATION}

Silicoflagellate assemblages of the Oligocene Naviculopsis biapiculata Zone, the Eocene Dictyocha hexacantha Zone and Naviculopsis foliacea Zone, and the Paleocene Naviculopsis constricta Zone occur in cores from Leg 43. These zones are discussed below from youngest to oldest.

\section{Naviculopsis biapiculata Zone (Bukry, 1974)}

This zone is identified only at Site 385 (Cores 2 and 3 ) on the basis of very sparse assemblages. Silicoflagellates are rare relative to the solution-resistant probable diatom Rocella gelida. Although the common occurrence of Distephanus crux crux, Naviculopsis biapiculata, and $R$. gelida at Site 385 are typical for the zone, some reworked Cretaceous specimens and the small number of silicoflagellates present prevent detailed correlation to other areas.

Dictyocha hexacantha Zone (Bukry and Foster, 1974)

A few specimens of Dictyocha hexacantha s. str. occur in Core 14 at Site 386 in assemblages that contain abundant Macrora barbadensis and common Corbisema triacantha triacantha and Naviculopsis foliacea. A similar assemblage was reported from nearby DSDP Site 6 (Bukry and Foster, 1974). Both assemblages coexist with upper middle Eocene coccoliths such as Chiasmolithus grandis and Reticulofenestra umbilica. Although more poorly preserved, the same association is noted at DSDP Site 29; this suggests that the great bloom of $M$. barbadensis in the western North Atlantic Ocean was about the time of the late middle Eocene appearance of the coccolith $R$. umbilica.

Naviculopsis foliacea Zone (Martini, 1974; emended, Bukry, 1977a)

Dictyocha spinosa Subzone (Bukry, 1977a)

Assemblages of the Dictyocha spinosa Subzone, defined between the appearances of Dictyocha spinosa and $D$. hexacantha, occur in Cores 4 and 6 at Site 385 and in Cores 15 to 17 at Site 386. Corbisema triacantha triacantha and Naviculopsis foliacea are common at both sites. A reversal in the ratio of $C$. triacantha triacantha to Dictyocha deflandrei lobata between the two sites suggests the assemblages at Site 385 are older because the sites are closely located and at similar depths. Coccoliths of the middle Eocene Nannotetrina quadrata Zone are associated with the silicoflagellate assemblages at Site 386.

Naviculopsis constricta Zone (Bukry and Foster, 1974)

The Naviculopsis constricta Zone, originally bounded by the appearances of Naviculopsis constricta at the base and Dictyocha hexacantha at the top, has been shortened by the replacement of $D$. hexacantha by the first Naviculopsis foliacea (Bukry, 1977a). Assemblages of the lower part of the $N$. constricta Zone occur in Cores 6 and 7 at Site 384. Naviculopsis danica and $N$. constricta, together, constitute 60 percent to 88 percent of the assemblages and suggest possible correlation to the Paleocene and Eocene diatomites at Fur and Mors in Denmark (Perch-Nielsen, 1976). Coccoliths in Cores 6 and 7 belong to the upper Paleocene Discoaster mohleri Zone and D. nobilis Zone.

A local subzonation of the Naviculopsis constricta Zone proposed for the Moler Formation of Denmark by Perch-Nielsen (1976) cannot be applied at Site 384 because the Danish sequence of subzonal guide species-Naviculopsis danica, Dictyocha elongata, and Corbisema disymmetrica communis (syn. C. naviculoidea)-all co-occur in the deepest silicoflagellate assemblage at Site 384, and that level is associated with upper Paleocene Discoaster mohleri Zone coccoliths.

\section{SILICOFLAGELLATE TAXONOMY}

\section{Genus CORBISEMA Hanna, 1928}

\section{Corbisema apiculata (Lemmermann)}

Dictyocha triacantha var. apiculata Lemmermann, 1901, p.259, pl. 10 , fig. $19,20$.

Corbisema apiculata (Lemmermann), Perch-Nielsen, 1975, p. 685, pl. 2 , fig. 15, 16, 19; pl. 3, fig. 19, 20, 24; pl. 15, fig. 1, 2 .

Corbisema apiculata (Lemmermann), Bukry, 1975c, p. 853, pl. 1, fig. 2.

Remarks: Some slightly isosceles specimens of this typically moderate to large equilateral species occur at Site 386 in the middle Eocene.

\section{Corbisema archangelskiana (Schulz)}

Dictyocha triacantha archangelskiana Schulz, 1928, p. 250, fig. 33a-c, 77 (not fig. 78). 
Corbisema archangelskiana (Schulz), Perch-Nielsen, 1975, p. 685, pl. 3 , fig. $17,22$.

\section{Corbisema bimucronata bimucronata Deflandre}

(Plate 1, Figures 1, 2)

Corbisema bimucronata Deflandre, 1950, p. 191, fig. 174-177.

Corbisema bimucronata Deflandre, Perch-Nielsen, 1975, p. 685, pl. 3, fig. 17, 21 .

Remarks: Spined and blunt forms of this species occur in the middle Eocene at Site 385. Both have the blunt segment perpendicular to the bisectrix of the portal. Eocene assemblages at Site 385 and Paleocene assemblages at Site 384 also contain double-spined specimens of Corbisema sp. cf. C. hastata hastata, C. sp. cf. C. hastata minor, and $C$. sp. $\mathrm{cf}$. $C$. inermis inermis that mimic $C$. bimucronata bimucronata. No specimens of $C$. bimucronata rotatoria are present.

Corbisema bimucronata rotatoria Bukry

Corbisema bimucronata rotatoria Bukry, 1977b, p. 702, pl. 1, fig. 6,7 .

\section{Corbisema disymmetrica communis Bukry}

(Plate 1, Figures 3, 4)

Corbisema disymmetrica communis Bukry, 1976a, p. 891, pl. 1, fig. 5-9.

\section{Corbisema glezerae Bukry}

Corbisema glezerae Bukry, 1976a, p. 892, pl. 3, fig. 1-7.

Remarks: Rare specimens of Corbisema glezerae in Core 6 at Site 384 have the size and proportions of typical specimens from the Falkland Plateau stratotype, but differ by having one or less septa.

\section{Corbisema hastata globulata Bukry}

Corbisema hastata globulata Bukry, 1976a, p. 892, pl. 4, fig. 1-8.

Remarks: Corbisema hastata globulata is isosceles and smaller than C. apiculata.

\section{Corbisema hastata hastata (Lemmermann)}

(Plate 1, Figures 5, 6)

Dictyocha triacantha hastata Lemmermann, 1901, p. 259, pl. 10, fig. 16-17.

Corbisema hastata hastata (Lemmermann), Bukry, 1976a, p. 892, pl. 4, fig. 9-16.

Remarks: Most specimens of Corbisema hastata hastata from Leg 43 are more broadly isosceles than those from Leg 36 on the Falkland Plateau.

\section{Corbisema hastata minor (Schulz)}

Dictyocha triacantha apiculata minor Schulz, 1928 (in part), p. 249, fig. 29b.

Corbisema hastata minor (Schulz), Bukry, 1975c, p. 854, pl. 1, fig. 10.

\section{Corbisema inermis inermis (Lemmermann)}

Dictyocha triacantha inermis Lemmermann, 1901, p. 259, pl. 10, fig. 21.

Corbisema inermis inermis (Lemmermann), Bukry, 1976a, p. 892, pl. 5, fig. 1-3.

\section{Corbisema inermis minor (Glezer)}

$$
\text { (Plate 1, Figure 7) }
$$

Dictyocha triacantha var. inermis f. minor Glezer, 1966, p. 247, pl. 8 , fig. 3-5; pl. 31, fig. 7 .

Corbisema inermis minor (Glezer) Bukry, 1976a, p. 892, pl. 5, fig.4-7.

\section{Corbisema neoparallela Bukry}

Corbisema neoparallela Bukry, 1976a, p. 893, pl. 5, fig. 8-13.

\section{Corbisema triacantha triacantha (Khrenberg)}

(Plate 1, Figure 8)

Dictyocha triacantha Ehrenberg, 1844, p. 80.

Corbisema triacantha triacantha (Ehrenberg), Bukry, 1977b, p. 702, pl. 1. fig. 13-15.

Remarks: No specimens having asymmetric strut attachment to the basal ring-Corbisema triacantha mediana (see Bukry, 1977b)occur in Leg 43 samples. The small rounded variant $C$. triacantha minor (see Ling, 1972) was not distinguished in counts for $C$. triacantha triacantha.

\section{Genus CORNUA Schulz, 1928}

\section{Cornua trifurcata Schulz, 1928}

(Plate 1, Figure 9)

Cornua trifurcata Schulz, 1928, p. 285, fig. 83a-c.

Remarks: Rare, broken specimens of Cretaceous Cornua trifurcata are present in upper Oligocene Cores 2 and 3 at Site 385. They are, however, concentrated in greater numbers in these cores relative to Lyramula furcula than in indigenous Cretaceous assemblages, suggesting they may be highly resistant to dissolution.

\section{Genus DICTYOCHA Ehrenberg, 1837}

\section{Dictyocha brevispina (Lemmermann)}

Dictyocha fibula var. brevispina Lemmerman, 1901, p. 260; Ehrenberg, 1854 (in part), pl. 21, fig. 42 b; pl. 22, fig. 42 a, b.

Remarks: A few Eocene specimens of Dictyocha approach the size and form of Dictyocha brevispina or D. pulchella, but no direct lineages are known between the Eocene and Neogene specimens. Until more detailed studies are done, they are tabulated as Dictyocha sp. aff. D. brevispina for the Eocene at Sites 385 and 386 (see Plate 1, Figure 10).

\section{Dictyocha deflandrei bicornuta Glezer}

Dictyocha deflandrei bicornuta Glezer, 1966, p. 264, pl. 12, fig. 20-23. Remarks: Dictyocha deflandrei bicornuta is distinguished by Glezer from $D$. deflandrei producta by the absence of minor-axis spines and by a circular to elliptic basal ring.

\section{Dictyocha deflandrei completa Glezer}

Dictyocha deflandrei Frenguelli, 1940 (in part), p. 65, fig. 14f.

Dictyocha deflandrei completa completa Glezer, 1966, p. 262, pl. 12, fig. 14,15 .

Dictyocha medusa Haeckel, Perch-Nielsen, 1975, p. 686, pl. 4, fig. $4(?), 5$; pl. 15 , fig. 5-7.

Dictyocha pentagona (Schulz), Perch-Nielsen, 1975, p. 687, pl. 5, fig. 11 ; pl. 15 , fig. 4 .

Dictyocha deflandrei Frenguelli ex Glezer, Bukry (1975c), p. 854, pl. 2, fig. 9-13.

Dictyocha deflandrei Frenguelli, Ciesielski, 1975, p. 672, pl. 4. fig. 7-9.

Dictyocha variabilis (Hanna), Ciesielski, 1975, p. 660, pl. 7, fig. 12-15.

Dictyocha deflandrei Frenguelli ex Glezer, Bukry, 1975a, p. 716, pl. 1 , fig. 7-10.

Remarks: To distinguish Dictyocha deflandrei completa from $D$. deflandrei deflandrei, Glezer (1966) stressed the completely open nature of the canals through the apical structure. Critical comparison of both Eocene $D$. deflandrei deflandrei, illustrated by Glezer and Frenguelli, and $D$. deflandrei lobata to Oligocene $D$. deflandrei completa from Antarctic DSDP sites shows that the morphology of the apical plate also helps to distinguish these forms. As a population, $D$. deflandrei completa has an apical plate smaller, thicker, and less consistently square in outline than on the other subspecies. The late Eocene or early Oligocene specimen from the Ivdel'skiy area of the Ural Mountains, illustrated in pl. 12, fig. 15 of Glezer (1966), is herein designated the lectotype. This subspecies is dominantly quadrate; the most common variants are pentagonal (Bukry, 1975c). 
Dictyocha deflandrei deflandrei Frenguelli ex Glezer

Dictyocha deflandrei Frenguelli, 1940, (in part), p. 65, fig. 14 a, d. Dictyocha deflandrei deflandrei Frenguelli, Glezer, 1966, p. 262, pl. 12, fig. 13, 16; pl. 32, fig. 4.

Remarks: Dictyocha deflandrei deflandrei was defined by Glezer (1966) to include the specimens illustrated by Frenguelli (1940) that have a square basal ring and canals that terminate at the corners of the apical plate. Whereas closure of the canals might be produced by environmental or secondary diagenetic processes, the square basal ring and large, thin, square plate help to distinguish $D$. deflandrei deflan$d r e i$ as a distinctive subspecies. The Eocene specimen from Fur, Denmark, illustrated in fig. 14a of Frenguelli (1940), is designated the lectotype.

\section{Dictyocha deflandrei producta Glezer, n. comb.}

Dictyocha deflandrei completa producta Glezer, 1966, p. 263, pl. 12 fig. 17-19.

Remarks: Dictyocha deflandrei producta is distinguished from $D$. deflandrei completa by major-axis spines that are more than twice as long as those of the minor axis.

\section{Dictyocha deflandrei lobata $\mathbf{n}$. subsp.} (Plate 1, Figures 11-17)

Description: Dictyocha deflandrei lobata has a basal ring that is generally in the form of a rounded, lobate, slightly elongate rhomb. The four corners are broadly rounded and have narrow, short spines that are typically less than the distance to the adjacent strut junctions. Equant and symmetrically arranged struts join a large, thin apical plate. The plate occupies approximately a third of the minoraxis diameters, and whereas it is square in format, the margins are slightly concave. The ratio of the major to minor axis of the basal ring varies, ranging from $1 / 1$ to $1.2 / 1.0$.

Remarks: Dictyocha deflandrei lobata is distinguished from both $D$. deflandrei deflandrei and $D$. deflandrei completa by its much smaller and inequant spines and by the lobate form of its basal ring (compare Frenguelli, 1940). Although most of the specimens of $D$. deflandrei lobata from Sites 385 and 386 are typical, rare variants having apical bars rather than plates, or variants with one set of angular corners are present.

Occurence: Dictyocha deflandrei lobata is common in the lower part of the Eocene Dictyocha spinosa Subzone at Site 385 and rare in the upper part of that subzone at Site 386.

Size: $20-40 \mu \mathrm{m}$, maximum internal diameter.

Holotype: USNM 242670 (Plate 1, Figure 13).

Isotypes: USNM 242671 to 242676.

Type locality: Northwest Atlantic Ocean, Sample 385-4-3, 130$132 \mathrm{~cm}(140 \mathrm{~m})$.

\section{Dictyocha elongata Glezer}

(Plate 1, Figure 18; Plate 2, Figures 1-3)

Dictyocha elongata Glezer, 1960, p. 131, 132, table 1, pl. 2, fig. 16-20. Dictyocha elongata Glezer, Glezer, 1966 (in part), p. 254, fig. 18 (4-7, not 8); pl. 11, fig. 1-4, 6, and 7 (not 5).

Remarks: Dictyocha elongata is structurally similar to Naviculopsis danica. It can be distinguished in the late Paleocene at Site 384 by its broader basal ring, three-spined format, and proportionally shorter axial spines. Even when the basal ring is more prolongate than triangular, the axial spines are shorter than the major axis of the ring, whereas, $N$. danica has spines that are equal to or longer than the major axis diameter. Stratigraphically, $D$. elongata is present throughout the range of $N$. danica at Site 384. It is most abundant in the deepest Sample 384-7-3, 100-101 cm (112 m).

\section{Dictyocha hexacantha Schulz}

Dictyocha hexacantha Schulz, 1928, p. 255, fig. 43.

Corbisema hexacantha (Schulz) Deflandre, 1950, p. 192, fig. 183-187.

\section{Dictyocha spinosa (Deflandre)}

Corbisema spinosa Deflandre, 1950, p. 193, fig. 178-182.

Dictyocha spinosa (Deflandre) Glezer, 1966, p. 256, pl. 10, fig. 6-8.
Dictyocha sp. A.

(Plate 2, Figures 4, 5)

Remarks: Some minor variants of Eocene Dictyocha are more distinctive than others. Because of sporadic occurrence, their small numbers, and a lack of distinctive morphologies, it may take some time to determine their possible stratigraphic and paleoecologic significance. The most distinctive such morphotype from DSDP Leg 43 is tabulated as Dictyocha sp. A., from Site 385 (Cores 4 and 6) and Site 386 (Cores 14 to 17).

Dictyocha sp. A. has a moderate-sized basal ring that is bowedout at the asymmetric strut junctions producing a nearly eight-sided outline. Four, broad, short basal pikes are located well away from the strut junctions in a clockwise sense of rotation in apical view. Spines are short to moderate. The apical bar is short to moderate and is slightly canted, but close to the minor axis alignment in most specimens. Fibuloid forms are less common.

\section{Genus DISTEPHANUS Stöhr, 1880}

\section{Distephanus crux crux (Ehrenberg)}

(Plate 2, Figures 8, 9)

Dictyocha crux Ehrenberg, 1840, p. 207; Ehrenberg, 1854, pl. 18, fig. 56 ; pl. 20 (1), fig. 46 ; pl. 33 (15), fig. 9; pl. 33 (16), fig. 9; pl. 33 (17), fig. 5 .

Remarks: Specimens of Distephanus crux crux from the upper Oligocene at Site 385 have small basal pikes and moderate to large apical rings. They are very similar to the more common cosmopolitan populations of the Miocene. A few specimens from the Eocene tabulated as $D$. crux s. ampl. appear to lack basal pikes.

\section{Distephanus polyactis (Ehrenberg)}

(Plate 2, Figure 10)

Dictyocha polyactis Ehrenberg, 1839, p. 129; Ehrenberg 1854, pl. 22 fig. 50.

Distephanus polyactis (Ehrenberg), Dumitrică, 1973 (in part), p. 851 , pl. 7 , fig. $10,12,13$; pl. 8 , fig. $1-10$; pl. 9, fig. 2 .

Remarks: A single seven-sided, short-spined, unpiked irregular specimen was encountered from the middle Eocene of Sample 386$17-1,88-89 \mathrm{~cm}(386 \mathrm{~m})$.

\section{Distephanus raupii Bukry}

(Plate 2, Figure 15)

Distephanus speculum pentagonus (Lemmermann), Bukry, 1975c, (in part), p. 866, pl. 4, fig. 9, 10.

Distephanus raupii Bukry, 1976a, p. 895, pl. 7, fig. 14, 15.

Distephanus raupii Bukry, Bukry, 1976b, pl. 1, fig. 16-18.

Distephanus speculum binoculus (Ehrenberg)

Dictyocha binoculus Ehrenberg, 1844, p. 63, 79; Ehrenberg, 1854, pl. 19, fig. 2.

\section{Distephanus speculum pentagonus Lemmermann} (Plate 2, Figure 11)

Distephanus speculum var. pentagonus Lemmermann, 1901, p. 264, pl. 11, fig. 19.

Remarks: The few specimens tabulated as Distephanus speculum pentagonus are moderate sized and have moderate to large, angular apical rings. They all lack basal pikes; this distinguishes them from the Neogene type species (Bukry, 1976a).

\section{Distephanus speculum quintus (Bukry and Foster) (Plate 2, Figure 12)}

Cannopilus quintus Bukry and Foster, 1973, p. 826, pl. 1, fig. 8, 9; pl. 2, fig. 1 .

Distephanus speculum quintus (Bukry and Foster) Bukry, 1975c, p. 855.

Remarks: Distephanus speculum quintus was the first validly proposed epithet for pentagonal specimens with a multiply divided apical ring, as Dictyocha varibilis Hanna and Distephanus speculum 
cannopiloides (Proshkina-Lavrenko) Glezer were invalid by ICBN arts. 32, 33, and 63 (Bukry 1975c, and Loeblich et al., 1968). A question still remains as to whether $D$. speculum quintus, having a Neogene type suite with only few apical divisions, can be lineally connected to multiply divided Eocene forms. The problem of distinguishing minor varieties of the $D$. boliviensis stock that mimic those of the D. speculum stock is also unresolved. In its present usage, $D$. speculum quintus represents a composite group which may include pentagonal subdivided variants from both stocks.

\section{Distephanus speculum speculum (Ehrenberg)}

(Plate 2, Figures 13, 14)

Dictyocha speculum Ehrenberg, 1839, p. 150; Ehrenberg, 1854, pl. 18, fig. 57 ; pl. 19, fig. 41 ; pl. 21 , fig. 44 ; pl. 22 , fig. 47.

Remarks: No specimens of Distephanus speculum speculum occur in the Paleocene at Site 384. Typical specimens bearing basal pikes, but short spines, are most common in the upper Oligocene at Site 385 .

\section{Distephanus speculum triommata (Ehrenberg)}

Dictyocha triommata Ehrenberg, 1845, p. 56, 76; Ehrenberg 1854, pl. 33 (XV), fig. 11.

Dictyocha triommata Ehrenberg, Locker, 1974, p. 639, 634, pl. 4, fig. 5.

\section{Genus LYRAMULA Hanna, 1928}

\section{Lyramula furcula Hanna}

(Plate 2, Figures 16-18)

Lyramula furcula Hanna 1928, p. 262, pl. 41, fig. 4, 5 .

Remarks: Lyramula furcula, a Cretaceous guide fossil, occurs as broken, reworked specimens in upper Oligocene Cores 2 and 3 at Site 385 . Only simple wishbone-shaped forms are present. During photography for Eocene Sample 386-15-3, 100-101 cm (351 m), and after counts were completed, a single reworked specimen of $L$ furcula was encountered. These are the first reported occurrences of L. furcula from Atlantic Ocean cores. Except for breakage, the specimens are well preserved, suggesting they were probably derived from a local source. Previous known occurrences of $L$. furcula are in California, Siberia, and the Arctic, Indian, Pacific, and Southern oceans.

\section{Lyramula simplex Hanna}

Lyramula simplex Hanna, 1928, p. 262, pl. 41, fig. 6.

Remarks: Lyramula simplex is represented by typical unspined forms at Site $\mathbf{3 8 5}$ and by compared specimens that have a widened arch. Both forms are reworked from Cretaceous deposits.

\section{Genus MESOCENA Ehrenberg, 1843}

\section{Mesocena apiculata apiculata Schulz} (Plate 2, Figure 19)

Mesocena oamaruensis apiculata Schulz, 1928, p. 240, fig. 11. Mesocena apiculata (Schulz), Bukry, 1975c (in part), p. 856, pl. 5, fig. $6,8$.

Remarks: Mesocena apiculata apiculata has a ring in the form of an equilateral triangle with straight or slightly convex sides.

\section{Mesocena apiculata curvata Bukry}

Mesocena apiculata (Schulz), Bachmann, 1970 (in part), p. 280, pl. 5, fig. $10-13,15$.

Mesocena apiculata (Schultz), Bukry, 1975c (in part), p. 856, pl. 5, fig. 7.

Mesocena apiculata curvata Bukry, 1976b, p. 854, pl. 2, fig. 15, 16.

Remarks: Mesocena apiculata curvata has a distinctly isosceles ring that is commonly indented along the shorter side. It is most common in the upper range of the $M$. apiculata group.

\section{Mesocena apiculata inflata $\mathrm{n}$. subsp.}

(Plate 3, Figures 1-3)

?Mesocena polymorpha var. triangula (Ehrenberg), Tsumura, 1963 (in part) p. 36 , pl. 5 , fig. 1 ; pl. 17, fig. 7.

Mesocena apiculata (Schulz), Bukry, 1975c (in part), p. 856, pl. 5, fig. 8 .

?Septamesocena apiculata (Schulz), Perch-Nielsen, 1975 (in part), p. 689 , pl. 10, fig. 7.

Description: Mesocena apiculata inflata has a small to moderate triangular basal ring, typically equilateral, with distinctly convex sides. The ring is unornamented and the spines are short and in the plane of the ring.

Remarks: Mesocena apiculata inflata is distinguished from $M$. apiculata apiculata by smaller size and greater curvature of the ring. It is distinguished from $M$. triangula (see Ehrenberg, 1854, and Locker, 1974) by its unnoded surface and more equilateral shape.

Occurrence: Mesocena apiculata inflata occurs in the middle or early Eocene at Site 385; it is missing in the Oligocene at that site. The specimens in synonymy also are reported only from the Eocene at DSDP Sites 281 and 283, and Jackson's Paddock, Oamaru, New Zealand, and the Kreyenhagen Formation of California. The full range has to be determined, but $M$. apiculata inflata appears to be an early subspecies of the $M$. apiculata group.

Size: $40-50 \mu \mathrm{m}$, maximum internal diameter.

Holotype: USNM 242677 (Plate 3, Figure 3).

Isotypes: USNM 242678 and 242679. m).

Type locality: Northwest Atlantic Ocean, Sample 385-6, CC (156

\section{Mesocena? connudata $\mathrm{n} . \mathrm{sp}$.}

(Plate 3, Figures 4, 5)

Description: Mesocena? connudata has a simple, pennate, unornamented, unspined basal ring that is bilaterally symmetric. The periphery is sharply arched along the major-axis intercepts and smoothly convex along the minor-axis intercepts. The ratio of major to minor axis is 1.4 to 1.8 based on 7 specimens; the holotype is 1.7.

Remarks: The assignment of Mesoceria? connudata to the genus Mesocena is questioned because its shape and stratigraphic occurrence suggest it may be related to Corbisema disymmetrica angulata (see Bukry, 1976a; pl. 1, fig. 1-4). The lack of any cross-bar in $M$.? connudata, and the straighter sides of $C$. disymmetrica angulata help to distinguish the two. $M$. ? connudata is distinguished from $M$. ovata by its more angular arch, and $M$. venusta by its nonquadrate outline.

Occurrence: Mesocena? connudata occurs rarely in the upper Paleocene Naviculopsis constricta Zone at Site 384, where it co-occurs with Corbisema disymmetrica communis, but where its possible morphotype $C$. disymmetrica angulata is missing. It was not observed in younger strata from Leg 43 .

Size: $60-90 \mu \mathrm{m}$, maximum internal diameter.

Holotype: USNM 242680 (Plate 3, Figure 4).

Isotype: USNM 242681

Type locality: Northwest Atlantic Ocean, Sample 384-6-3, 100$101 \mathrm{~cm}(103 \mathrm{~m})$.

\section{Mesocena oamaruensis Schulz \\ Mesocena oamaruensis Schulz, 1928, p. 240 , fig. 10 a, b.}

\section{Mesocena occidentalis Hanna ex Bukry}

Mesocena occidentalis Hanna, 1931, p. 200, pl. E, fig. 1. Mesocena occidentalis Hanna, Perch-Nielsen, 1975, p. 688, pl. 10, fig. 15-16.

Mesocena occidentalis Hanna ex Bukry, Bukry, 1977a, p. 834.

\section{Mesocena ovata $\mathrm{n} . \mathbf{s p}$. \\ (Plate 3, Figure 6)}

Description: Mesocena ovata is a simple, symmetric, elliptic ring. The outline is unornamented. The ratio of major to minor axis is about 1.6 .

Remarks: Mesocena ovata is distinguished from elliptic variants of $M$. circulus by its lack of obvious surface ornamentation. It is distinguished from $M$. ? connudata by regular elliptic curvature. 
Occurrence: Mesocena ovata is rare in the middle Eocene at DSDP Sites 385 and 386 and in the upper Paleocene at Site 384.

Size: $80-90 \mu \mathrm{m}$, maximum internal diameter.

Holotype: USNM 242682 (Plate 3, Figure 6).

Type locality: Northwest Atlantic Ocean, Sample 384-7-1, 105 $106 \mathrm{~cm}(109 \mathrm{~m})$.

\section{Mesocena venusta Bukry}

(Plate 3, Figures 7, 8)

Mesocena venusta Bukry, in 1977a, p. 834, pl. 1, figs. 11-13.

Remarks: Mesocena venusta is an unspined rhomboid ring with rounded corners. It was first described from the middle Eocene near the boundary between the Dictyocha hexacantha Zone and Naviculopsis foliacea Zone at DSDP Site 356 in the South Atlantic. It occurs at the same stratigraphic position in Cores 14 and 15 at Site 386 in the North Atlantic.

\section{Genus NAVICULOPSIS Frenguelli, 1940}

\section{Naviculopsis biapiculata (Lemmermann)}

(Plate 3, Figures 9, 10)

Dictyocha navicula biapiculata Lemmerman, 1901, p. 258, pl. 10, fig. 14,15 .

Dictyocha regularis Carnevale, 1908, p. 35, pl. 4, fig. 28.

Naviculopsis biapiculata (Lemmermann) s.l., Dumitrică, 1973 (in part), p. 847 , pl. 1 , fig. 4 .

Naviculopsis biapiculata (Lemmermann), Bukry, 1975c; p. 856, pl. 6. fig. 5-8.

Remarks: The long-spined specimens of Naviculopsis biapiculata with high-arched bar that characterize the upper Oligocene at high latitude (Bukry, 1977a) are rare in the upper Oligocene of Cores 2 and 3 at Site 385. The more common associated species at low latitude, Naviculopsis eobiapiculata, has a longer range, from the Paleocene or Eocene to Oligocene.

\section{Naviculopsis constricta (Schulz)}

(Plate 3, Figures 11, 12)

Dictyocha navicula biapiculata constricta Schulz, 1928, p. 246, fig. 21.

Remarks: Several large banded specimens having elongate basal rings are tabulated as compared specimens (Plate 3, Figures 13,14.) Another variation, tabulated as semibarred, has the apical band constricted to a bar at the center.

\section{Naviculopsis danica Perch-Nielsen}

(Plate 3, Figure 15; Plate 4, Figures 1-8)

Dictyocha elongata Glezer, 1966 (in part), p. 254, fig. 18 (8); pl. 11, fig. 5 .

Naviculopsis danica Perch-Nielsen, 1976, p. 35, fig. 5, 6, 21.

Naviculopsis danica Perch-Nielsen, Bukry, 1976a, p. 897, pl. 9, fig. 3.

Remarks: Initially described from the Moler Formation of Denmark Naviculopsis danica is a dominant species in the upper Paleocene of Site 384. Typical specimens have axial spines that are equal to or longer than the ring. The position of the three-strut apical structure is variable. Rare variants have a four-strut arrangement or have the struts flattened into bands.

\section{Naviculopsis eobiapiculata $\mathbf{n}$. sp.} (Plate 4, Figures 9-16)

Naviculopsis biapiculata (Lemmermann), Ling 1972 (in part) p. 181, pl. 30 , fig. 3,4 .

Naviculopsis regularis (Carnevale), Ling, 1972 (in part), p. 188, pl. 31 , fig. 3 .

Naviculopsis biapiculata (Lemmermann) s.l., Dumitrică, 1973, p. 847 , pl. 1 , fig. $5,9,10(?)$.

Naviculopsis biapiculata (Lemmermann) s.l., Perch-Nielsen, 1975 (in part), p. 689 , pl. 12 , fig. $18,20,21$.

Naviculopsis biapiculata (Lemmermann), Bukry, 1975c (in part), p. 856 , pl. 6 , fig. 6 .

Description: Naviculopsis eobiapiculata has a large elongate basal ring with sides that are essentially straight near the apical bar junction; the axial ends are rounded. The long axial spines are typically greater than one half as long as the basal ring but are variable. The ratio of length to width of the basal ring varies from 2.1 to 3.0 for Oligocene specimens and 2.5 to 4.5 for Eocene specimens from DSDP Leg. 43.

Remarks: Naviculopsis eobiapiculata is distinguished from $N$. biapiculata by its urounded and proportionally much longer basal ring. The apical bar is less arched. N. eobiapiculata appears to be the evolutionary source for such species as $N$. biapiculata s. str. and $N$. lata. Both appeared near the end of the range of $N$. eobiapiculata and have common structural elements but different proportions.

Occurrence: Naviculopsis eobiapiculata is present in Eocene samples from Sites 385 and 386 and in Oligocene samples from Site 385 . The specimens cited in synonymy range from upper Eocene to upper Oligocene. Two compared specimens were recorded from the Paleocene of Site 384.

Size: $30-45 \mu \mathrm{m}$, maximum internal diameter.

Holotype: USNM 242683 (Plate 4, Figure 9.)

Isotypes: USNM 242684 to 242690 .

Type locality: Northwest Atlantic Ocean, Sample 385-4-3, 130$132 \mathrm{~cm}(140 \mathrm{~m})$.

Naviculopsis foliacea Deflandre

Naviculopsis foliacea Deflandre, 1950, p. 204, fig. 235-240.

Naviculopsis lata (Deflandre)

Dictyocha biapiculata lata Deflandre, 1932, p. 500, fig. 30, 31.

Remarks: A few Paleocene compared specimens from Site 384 resemble lower Miocene Naviculopsis lata, which has been considered conspecific with a similar Eocene form, $N$. robusta Deflandre (1950). The presence of the few specimens of $N$. sp. aff. $N$. lata in the Paleocene, however, suggests that $N$. lata and $N$. robusta may be convergent homeomorphs instead of synonyms.

\section{GENERA INCERTAE SEDIS TAXONOMY}

Genus MACRORA Hanna, 1932

(Synonym: Pseudorocella Deflandre, 1938)

Remarks: Hanna (1932) considered Macrora to be a genus of diatoms by his statement: "I have had an opportunity to study several specimens in all positions and can state confidently that the organism is a diatom. .." Deflandre (1938) validated genus Pseudorocella as a questionable silicoflagellate. Pseudorocella corona Deflandre (1947) is a junior synonym of Macrora stella (Azpeitia) Hanna (1932). Neither this nor other species assigned to the genus can be definitely considered diatoms or silicoflagellates on the basis of present evidence (Lipps, 1970; Schrader, 1973). The three species herein assigned to the extinct genus Macrora are considered of uncertain origin because of small size and unusual form, but are treated with the silicoflagellates for stratigraphic purposes in the same manner that Discoaster, an extinct incertae sedis genus of calcareous nannoplankton, is treated in coccolith studies.

\section{Macrora barbadensis (Deflandre)}

(Plate 4, Figures 18, 19)

Pseudorocella barbadensis Deflandre, 1938 (in part), p. 91, fide Loeblich et al., 1968, p. 139, pl. 33, fig. 4-13, 15-19 (not 14).

Pseudorocella barbadensis Deflandre, Bukry and Foster, 1974, p. 307, fig. $2 f$.

Macrora barbadensis (Deflandre) Bukry, 1977a, p. 836, pl. 2, fig. 3-8.

Remarks: Macrora barbadensis is abundant in the Eocene lower Dictyocha hexacantha Zone at Site 386. This matches its occurrence at Site 356 in the South Atlantic.

\section{Macrora najae Bukry}

Macrora najae Bukry, 1977a, p. 836, pl. 2, fig. 9-12.

Remarks: A typical specimen of Macrora najae having elongate shape and bimodal pore groups occurs in the upper middle Eocene Dictyocha hexacantha Zone in Core 14 at Site 386. This level is assigned to the Discoaster bifax Subzone of coccoliths. At Site 356 in 


\section{BUKRY}

the South Atlantic, $M$. najae occurs in the same correlative zonal levels.

\section{Macrora stella (Azpeitia)}

(Plate 4, Figures 20, 21)

Pyxidicula (??) stella Azpeitia, 1911, p. 150, 152, 213, pl. 1, fig. 1. Macrora stella (Azpeitia) Hanna, 1932, p. 196, pl. 12, fig. 7. Pseudorocella corona Deflandre, 1947, p. 337, fig. 4.

Pseudorocella corona Deflandre, Stradner, 1961, p. 92, fig. 105, 106.

Remarks: A single specimen of circular multipored Macrora stella occurs in the upper Oligocene Naviculopsis biapiculata Zone at Site 385 .

\section{Genus ROCELLA Hanna, 1930}

REMARKS: Because of the similarity in form of the type species Rocella gemma and the diatom Stictodiscus gelidus Mann, R. gemma could be considered a junior synonym of the diatom species. Lipps (1970) suggested that the shape and large pores of $R$. gemma indicated it was probably a partly dissolved valve of a diatom. Side views of $R$. gemma (see Bukry, 1976a) demonstrated a pillboxshaped valve. Several double-valve sets of $R$. gemma are present in samples from Core 2 at Site 385. These double-valve sets suggest that strong dissolution has not been responsible for the unusual morphology of $R$. gemma, because there is no evidence of any substructure within the pores of these specimens. Neither these double-valve specimens, nor the previously illustrated specimens of $R$. gemma and $S$. gelidus are readily assignable to the diatom genus Stictodiscus. All of these specimens have a distinctive central pore or pore-pair surrounded by a thickened silica framework. And all specimens have distinctly larger pores and less solid valve area than any Stictodiscus. It is therefore proposed that Rocella be recognized as a genus of diatoms, that the type species is $R$. gelida (R. gemma being a junior synonym), and that the exceptionally large-pored forms that evolved near the top of the range of $R$. gelida be recognized as a new species $R$. schraderi.

Rocella gelida (Mann) n. comb.

(Plate 5, Figures 1-13)

Stictodiscus gelidus Mann, 1907, p. 268, pl. 50, fig. 5.

Stictodiscus gelidus Mann, Hanna, 1929, p. 296, pl. 34, fig. 1.

Rocella gemma Hanna, 1930 (in part), p. 415, pl. 40, fig. 1, 2, 4-9.

Rocella gemma Hanna, Dumitrică, 1973 (in part), p. 855, pl. 11, fig. 9-12.

Coscinodiscus vigilans Schmidt, Bukry, 1975a (in part), p. 722, pl. 4, fig. 2,3 .

Coscinodiscus sp. cf. C. vigilans Schmidt, Bukry, 1975a, p. 722, pl. 4, fig. 4-6.

Rocella gemma Hann, Perch-Nielsen, 1975 (in part), p. 883, pl. 11, fig. 6-9.

Stictodiscus gelidus Mann, Bukry, 1976a (in part), p. 916, pl. 9, fig. 5, 6,7 (lower), 8, 9.

Remarks: The holotype of Rocella gemma and Hanna's illustration of Stictodiscus gelidus both depict multipored specimens wherein numerous concentric cycles of pores are equant or decrease in size gradually toward the periphery. This serves to distinguish Rocella gelida from $R$. schraderi, which has a very large inner cycle or pores that is distinctly larger than the adjacent cycle. Because of the areal predominance of the inner cycle of pores, $R$. schraderi has fewer cycles of pores than $R$. gelida.

A difference of stratigraphic range between these two species suggests that $R$. gelida is the older of the two. Although the assemblage in Core 3 at Site 385 is more dissolved than that of Core 2 , it is further characterized by the presence of $R$. gelida without $R$. schraderi. $R$. schraderi first occurs in the Core 2 assemblages, and appears to be an evolutionary development from $R$. gelida.

Rocella schraderi $\mathrm{n}$. sp.

(Plate 6, Figures 1-10; Plate 7, Figure 1)

Rocella gemma Hanna, 1930 (in part), p. 415, pl. 40, fig. 3, 10, 11 Rocella gemma Hanna, Ling, 1972, p. 192, pl. 31, fig. 12-15. Rocella gemma Hanna, Bukry, 1973a, p. 892, pl. 1, fig. 9, 10.
Rocella gemma Hanna, Dumitrică, 1973 (in part), p. 855, pl. 11, fig. $7,8$.

Rocella gemma Hanna, McPherson and Ling, 1973, p. 478, pl. 2, fig. 3-9.

Rocella gemma Hanna, Bukry and Foster, 1974, p. 307, fig. 2 g, h. Rocella gemma Hanna, Bukry, 1975a (in part), p. 722, pl. 4, fig. 7-9. Rocella gemma Hanna, Perch-Nielsen, 1975 (in part), p. 883, pl. 11, fig. $1-5,10$.

Stictodiscus gelidus Mann, Bukry, 1976a (in part), p. 916, pl. 9, fig. 4, 7 (upper).

Description: Rocella schraderi valves are circular and flat with numerous small rounded pores near the periphery and four to six very large rounded polygonal pores around the center point. The distal surface of the valve is bent at right angles to form a marginal flange. There are two cycles of small pores in the marginal flange, approximately equal in size and number to the adjacent peripheral cycle of pores on the apical surface of the valve. The interpore bars of the large inner cycle expand to form a solid central area which contains a single- or double-perforated depression. Minor surface sculpture and buttressing ridges between the marginal flange and main disk are evident on some specimens (McPherson and Ling, 1973).

Remarks: Rocella schraderi is distinguished from $R$. gelida by having a central cycle of pores that is distincly larger than the adjacent cycle, and by the concomitant reduction in the number of pores on the apical surface of the valve.

Occurrence: Rocella schraderi has been reported from strata considered to be late Oligocene or earliest Miocene in age. It is associated with coccoliths of the Sphenolithus ciperoensis Zone at Site 206. Because of its great resistance to dissolution and the ease of identifying its central area, even in partial specimen form, it provides a convenient stratigraphic guide for the interval near the OligoceneMiocene boundary. The specimens in synonymy come from California, Baja California, Atlantic, Pacific, and Southern oceans.

Size: $40-80 \mu \mathrm{m}$, maximum diameter.

Holotype: USNM 242691 (Plate 6, Figures 5, 6).

Isotpyes: USNM 242692 to 242696.

Type locality: Northwest Atlantic Ocean, Sample 385-2-3, 90-91 $\mathrm{cm}(64 \mathrm{~m})$.

\section{COCCOLITH SPECIES CITED}

Arkhangelskiella cymbiformis Vekshina

Biantholithus sparsus Bramlette and Martini

Biscutum testudinarium Black

Braarudosphaera bigelowii (Gran and Braarud)

$B$. rosa Levin and Joerger

Bramletteius serraculoides Gartner

Campylosphaera dela (Bramlette and Sullivan)

C. eodela Bukry and Percival

Ceratolithus cristatus Kamptner

C. telesmus Norris

Chiasmolithus altus Bukry and Percival

C. bidens (Bramlette and Sullivan)

C. consuetus (Bramlette and Sullivan)

C. danicus (Brotzen)

C. expansus (Bramlette and Sullivan)

C. gigas (Bramlette and Sullivan)

C. grandis (Bramlette and Riedel)

C. oamaruensis (Deflandre)

C. solitus (Bramlette and Sullivan)

Chiphragmalithus acanthodes Bramlette and Sullivan

C. calathus Bramlette and Sullivan

Coccolithus crassus Bramlette and Sullivan

C. cribellum (Bramlette and Sullivan)

C. eopelagicus (Bramlette and Riedel)

C. formosus (Kamptner)

C. magnicrassus Bukry

C. miopelagicus Bukry

C. pelagicus (Wallich)

C. staurion Bramlette and Sullivan

C. subdistichus (Roth and Hay)

Cribrosphaera ehrenbergii Arkhangelsky

Cruciplacolithus tenuis (Stradner)

Cyclicargolithus abisectus (Müller) 
C. floridanus (Roth and Hay)

C. pseudogammation (Bouché)

Cyclococcolithina gammation (Bramlette and Sullivan)

C. leptopora (Murray and Blackman)

C.? lumina (Sullivan)

C. macintyrei (Bukry and Bramlette)

Cyclolithella? bramlettei (Hay and Towe)

Dictyococcites bisectus (Hay, Mohler, and Wade)

D. scrippsae Bukry and Percival

Discoaster araneus Bukry

D. barbadiensis Tan

D. cruciformis Martini

D. deflandrei Bramlette and Riedel

D. distinctus Martini

D. gemmeus Stradner

D. gemmifer Stradner

D. lodoensis Bramlette and Riedel

D. mirus Deflandre

D. mohleri Bukry and Percival

D. multiradiatus Bramlette and Riedel

D. nobilis Martini

D. nodifer (Bramlette and Riedel)

D. saipanensis Bramlette and Riedel

D. strictus Stradner

D. sublodoensis Bramlette and Sullivan

D. tanii (Bramlette and Riedel)

Discoasteroides kuepperi (Stradner)

D. megastypus Bramlette and Sullivan

Eiffellithus turriseiffeli (Deflandre)

Ellipsolithus distichus (Bramlette and Sullivan)

E. lajollaensis Bukry and Percival

E. macellus (Bramlette and Sullivan)

Emiliania annula (Cohen)

E. huxleyi (Lohmann)

E. ovata Bukry

Fasciculithus clinata Bukry

F. hayi $\mathrm{Haq}$

$F$. involutus Bramlette and Sullivan

F. schaubii Hay and Mohler

F. tympaniformis Hay and Mohler

Gephyrocapsa caribbeanica Boudreaux and Hay

G. oceanica Kamptner

Helicosphaera carteri (Wallich)

$H$. compacta Bramlette and Wilcoxon

H. euphratis Haq

H. lophota (Bramlette and Sullivan)

$H$. reticulata Bramlette and Wilcoxon

$H$. seminulum Bramlette and Sullivan

Heliolithus kleinpellii Bramlette and Sullivan

$H$. riedelii Bramlette and Sullivan

Heliorthus chiastus (Bramlette and Sullivan)

basionym: Zygolithus chiastus Bramlette and Sullivan, 1961,

Micropaleontology, v. 7, p. 149, pl. 6, fig. I a-d, 2 a-b, 3 a-b.

$H$. distentus (Bramlette and Sullivan)

basionym: Zygolithus distentus Bramlette and Sullivan, 1961,

Micropaleontology, v. 7, p. 150, pl. 6, fig. 4 a-c, 5, 6 a-d, 7 .

$H$. junctus (Bramlette and Sullivan)

basionym: Zygolithus junctus Bramlette and Sullivan, 1961,

Micropaleontology, v. 7, p. 150, pl. 6, fig. 11 a-b.

Isthmolithus recurvus Deflandre

Lophodolithus acutus Bukry and Percival

L. mochlophorus Deflandre

L. nascens Bramlette and Sullivan

L. rotundus Bukry and Percival

Markalius inversus (Deflandre)

Micrantholithus aequalis Sullivan

Micula decussata Vekshina

M. mura (Martini)

Nannotetrina alata (Martini)

Pedinocyclus larvalis (Bukry and Bramlette)

Pemma papillatum Martini

Prediscosphaera cretacea (Arkhangelsky)

Quinquerhabdus colossicus Bukry and Bramlette

Reticulofenestra dictyoda (Deflandre)

$R$. hillae Bukry and Percival
R. samodurovii (Hay, Mohler, and Wade)

R. umbilica (Levin)

Rhabdosphaera claviger Murray and Blackman

$R$. inflata Bramlette and Sullivan

$R$. tenuis Bramlette and Sullivan

Rhomboaster cuspis Bramlette and Sullivan

Scapholithus sp.

Scyphosphaera expansa Bukry and Percival

Sphenolithus anarrhopus Bukry and Bramlette

$S$. capricornutus Bukry and Percival

$S$. ciperoensis Bramlette and Wilcoxon

$S$. dissimilis Bukry and Percival

$S$. distentus (Martini)

S. moriformis (Brönnimann and Stradner)

S. obtusus Bukry

$S$. predistentus Bramlette and Wilcoxon

$S$. pseudoradians Bramlette and Wilcoxon

$S$. radians Deflandre

$S$. spiniger Bukry

Syracosphaera labrosa Bukry and Bramlette

Thoracosphaera operculata Bramlette and Martini

Toweius craticulus Hay and Mohler

T. eminens (Bramlette and Sullivan)

Transversopontis pulcher (Deflandre)

Tribrachiatus contortus (Stradner)

T. nunnii (Gartner)

Triquetrorhabdulus carinatus Martini

$T$. inversus Bukry and Bramlette

Umbilicosphaera sibogae Weber-van Bosse

Vermiculithina arca Bukry and Percival

Watznaueria barnesae (Black)

Zygodiscus adamas Bramlette and Sullivan

Z. sigmoides Bramlette and Sullivan

Z. spiralis Bramlette and Martini

Zygolithus dubius Deflandre

Zygrhablithus bijugatus (Deflandre)

\section{ACKNOWLEDGMENTS}

I thank Naja Mikkelsen, Scripps Institution of Oceanography, and John Barron, U.S. Geological Survey, for careful and constructive reviews that improved the manuscript. Helpful discussions with Hisatake Okada, Lamont-Doherty Geological Observatory, Ansis Kaneps, Scripps Institution of Oceanography, and James Crouch, U.S. Geological Survey, are also acknowledged. The manuscript was typed, assembled, and proofed with consummate skill by Dorothy Blackstock, U.S. Geological Survey.

\section{REFERENCES}

Azpeitia, D. F. M., 1911. La Diatomologia Española en los Comienzos des Siglo XX: Assoc. Esp. Prog. Cien. Congr. de Zargoza, v. 4, pt. 2, sec. 3, p. 1-320.

Bachmann, A., 1970. Silicoflagellaten aus dem oberösterreichischen Egerien (Oberoligozän): Österreichische Geol. Bundesanst. Verh., v. 2, p. 275-305.

Bukry, D., 1972. Further comments on coccolith stratigraphy, Leg 12, Deep Sea Drilling Project. In Berggren, W. A., Laughton, A. S., et al., Initial Reports of the Deep Sea Drilling Project, Volume 12: Washington (U.S. Government Printing Office), p. 1071-1083.

1973a. Coccolith and silicoflagellate stratigraphy, Tasman Sea and southwestern Pacific Ocean, Deep Sea Drilling Project Leg 21. In Burns, R. E., Andrews, J. E., et al., Initial Reports of the Deep Sea Drilling Project, Volume 21: Washington (U.S. Government Printing Office), p. 885-893.

, 1973b. Coccolith stratigraphy, eastern equatorial

Pacific, Leg 16 Deep Sea Drilling Project. In van Andel, T. H., Heath, G. R., et al., Initial Reports of the Deep Sea 
Drilling Project, Volume 16: Washington (U.S. Government Printing Office), p. 653-711.

1973c. Low-latitude coccolith biostratigraphic zonation. In Edgar, N. T., Saunders, J. B., et al., Initial Reports of the Deep Sea Drilling Project, Volume 15: Washington (U.S. Government Printing Office), p. 685703.

1974. Stratigraphic value of silicoflagellates in nontropical regions: Geol. Soc. Am. Bull., v. 85, p. 19051906.

1975a. Coccolith and silicoflagellate stratigraphy near Antarctica, Deep Sea Drilling Project Leg 28. In Hayes, D., Frakes, L. A., et al., Initial Reports of the Deep Sea Drilling Project, Volume 28: Washington (U.S. Government Printing Office), p. 709-723.

1975b. Coccolith and silicoflagellate stratigraphy, northwestern Pacific Ocean, Deep Sea Drilling Project Leg 32. In Larson, R. L., Moberly, R., et al., Initial Reports of the Deep Sea Drilling Project, Volume 32: Washington (U.S. Government Printing Office), p. 677701.

1975c. Silicoflagellate and coccolith stratigraphy, Deep Sea Drilling Project Leg 29. In Kennett, J. P., Houtz, R. E., et al., Initial Reports of the Deep Sea Drilling Project, Volume 29: Washington (U.S. Government Printing Office), p. 845-872.

1976a. Cenozoic silicoflagellate and coccolith stratigraphy, South Atlantic Ocean, Deep Sea Drilling Project Leg 36. In Craddock, C., Hollister, C. D., et al., Initial Reports of the Deep Sea Drilling Project, Volume 35: Washington (U.S. Government Printing Office), p. 885-917.

1976b. Silicoflagellate and coccolith stratigraphy, Norwegian-Greenland Sea, Deep Sea Drilling Project Leg 38. In Talwani, M., Udintsev, G., et al., Initial Reports of the Deep Sea Drilling Project, Volume 38: Washington (U.S. Government Printing Office), p. 845-856.

1977a. Coccolith and silicoflagellate stratigraphy, South Atlantic Ocean, Deep Sea Drilling Project Leg 39. In Perch-Nielsen, K., Supko, P. R., et al., Initial Reports of the Deep Sea Drilling Project, Volume 39: Washington (U.S. Government Printing Office), p. 825-840.

1977b. Cenozoic coccolith and silicoflagellate stratigraphy, offshore northwest Africa, Deep Sea Drilling Project Leg 41. In Lancelot, Y., Seibold, E., et al., Initial Reports of the Deep Sea Drilling Project, Volume 41: Washington (U.S. Government Printing Office), p. 689 708.

Bukry, D. and Foster, J. H., 1973. Silicoflagellate and diatom stratigraphy, Leg 16, Deep Sea Drilling Project. In van Andel, T. H., Heath, G. R., et al., Initial Reports of the Deep Sea Drilling Project, Volume 16: Washington (U.S. Government Printing Office), p. 815-871.

1974. Silicoflagellate zonation of Upper Cretaceous to lower Miocene deep-sea sediment: U.S. Geol. Survey J. Res., v. 2, p. 303-310.

Carnevale, P., 1908. Radiolarie e Silicoflagellati di Bergonzano (Reggio Emilia): Mem. R. Ist. Veneto Sci., Let. ed Arti, Venezia, v. 28, p. 1-39.

Ciesielski, P. F., 1975. Biostratigraphy and paleoecology of Neogene and Oligocene silicoflagellates from cores recovered during Antarctic Leg 28, Deep Sea Drilling Project: In Hayes, D., Frakes, L. A., et al., Initial Reports of the Deep Sea Drilling Project, Volume 28: Washington (U.S. Government Printing Office), p. 625-691.

Deflandre, G., 1932. Sur la systématique des Silicoflagellés: Soc. Bot. France Bull., v. 79, p. 494-506.
1938. Sur deux microfossiles siliceux énigmatiques (Silicoflagellidées?): Soc. France Microsc. Bull., v. 7, p. 90-96.

1947. Phyllodictyocha nov. gen., Silicoflagellidés et formes affines du Miocène de Hongrie: Soc. Bot. France Bull., v. 93, p. 335-337.

1950. Contribution a l'étude des silicoflagellidés actuels et fossiles: Microscopie, v. 2, p. 72-108, 117-142, and 191-210.

Dumitrică, P., 1973. Paleocene, late Oligocene and postOligocene silicoflagellates in southwestern Pacific sediments cored on DSDP Leg 21. In Burns, R. E., Andrews, J. E., et al., Initial Reports of the Deep Sea Drilling Project, Volume 21: Washington (U S. Government Printing Office), p. 837-883.

Ehrenberg, C. G., 1839. Über die Bildung der Kreidefelsen und des Kreidemergels durch unsichtbare Organismen: $K$. Preuss. Akad. Wiss.. Berlin Ber., Jahrg. 1838, p. 59-148.

1840. 274 Blätter von ihm selbst ausgeführter Zeichnungen von ebenso vielen Arten: $K$. Preuss. Akad. Wiss. Berlin Ber., Jahrg. 1840, p. 197-219.

1844. Mittheilung über zwei neue Lager von Gebirgsmassen aus Infusorien als Meeres-Absatz in NordAmerika und eine Vergleichung derselben mit den organischen Kreide-Gebilden in Europa und Afrika: $K$. Preuss. Akad. Wiss. Berlin Ber., Jahrg. 1844, p. 57-97.

1845. Neue Untersuchungen über das kleinste Leben als geologisches Moment.: K. Preuss. Akad. Wiss. Berlin Ber., Jahrg. 1845, p. 53-87. $1-374$.

1854. Mikrogeologie: Leipzig (Leopold Voss), p.

Frenguelli, J., 1940. Consideraciones sobre los sílicoflagelados fósiles: Mus. La Plata Rev., Paleontol., v. 2, p. 37-112.

Gartner, S., 1972. Late Pleistocene calcareous nannofossils in the Caribbean and their interoceanic correlation: Palaeogeogr., Palaeoclimatol., Palaeoecol., v. 12, p. 169-191.

Glezer, Z. I., 1960. Paleogenovye kremnevye zhgutikovye vodorosli (Silicoflagellatae) Zapadnoy Sibiri [Paleogene silicoflagellates of western Siberia]: Vses. Nauchno-Issled. Geol. Inst. Inform. Sbornik, Strat. i Paleont., no. 35, p. 127-136.

1966. Silicoflagellatophyceae. In Gollerbakh, M. M., (Ed.), Cryptogamic plants of the U.S.S.R.: Akad. Nauk SSSR, V. A. Komarova Bot. Inst. (Translated from Russian by Israel Program for Scientific Translations Ltd., Jerusalem, 1970), v. 7, p. 1-363.

Hanna, G. D., 1928. Silicoflagellata from the Cretaceous of California: J. Paleontol., v. 1, p. 259-263.

1929. Fossil diatoms dredged from Bering Sea: San Diego Soc. Nat. History Trans., v. 5, p. 287-296.

1930. A new genus of Silicoflagellata from the Miocene of Lower California: J. Paleontol., v. 4, p. 415416.

1931. Diatoms and silicoflagellates of the Kreyenhagen shale: California Div. Mines State Mineral. Rept., v. 27 , p. $187-201$.

, 1932. The diatoms of Sharktooth Hill, Kern County, California: Calif. Acad. Sci. Proc., v. 20, p. 161263.

Lemmermann, E., 1901. Silicoflagellatae: Deutsche. Bot. Gesell. Ber., v. 19, p. 247-271.

Ling, H. Y., 1972. Upper Cretaceous and Cenozoic silicoflagellates and ebridians: Am. Paleontol. Bull., v. 62, p. 135-229.

Lipps, J. H., 1970. Ecology and evolution of silicoflagellates: North American Paleontol. Conv. Proc., pt. G, p. 965-993. 
Locker, S., 1974. Revision der Silicoflagellaten aus der Mikrogeologischen Sammlung von C. G. Ehrenberg: Ecolog. Geol. Helv., v. 67, p. 631-646.

Loeblich, A. R., 3d, Loeblich, L. A., Tappan, H., and Loeblich, A. R., Jr., 1968. Annotated index of fossil and recent silicoflagellates and ebridians with descriptions and illustrations of validly proposed taxa: Geol. Soc. Am. Mem., v. 106, 319 p.

McPherson, L. M. and Ling, H. Y., 1973. Surface microstructure of selected silicoflagellates: Micropaleontology, v. 19, p. $475-480$.

Mann, A., 1907. Report on the diatoms of the voyages of the Albatross in the Pacific Ocean, 1888-1904: Contrib. U.S. Nat. Herb., Smithsonian Inst., v. 10, p. 221-442.

Martini, E., 1974. Silicoflagellate zones in the Eocene and early Oligocene: Senckenberg. Lethaea, v. 54, p. 527-532.

Perch-Nielsen, K., 1972. Remarks on Late Cretaceous to Pleistocene coccoliths from the North Atlantic. In Berggren, W. A., Laughton, A. S., et al., Initial Reports of the Deep Sea Drilling Project, Volume 12: Washington (U.S. Government Printing Office), p. 1003-1069. 1975. Late Cretaceous to Pleistocene silicoflagellates from the southern southwest Pacific, DSDP Leg 29.
In Kennett, J. P., Houtz, R. E., et al., Initial Reports of the Deep Sea Drilling Project, Volume 29: Washington (U.S. Government Printing Office), p. 677-721.

1976. New silicoflagellates and a silicoflagellate zonation in north European Palaeocene and Eocene diatomites: Geol. Soc. Denmark Bull., v. 25, p. 27-40.

Schrader, H.-J., 1973. Cenozoic diatoms from the northeast Pacific, Leg 18. In Kulm, L. D., von Huene, R., et al., Initial Reports of the Deep Sea Drilling Project, Volume 18: Washington (U.S. Government Printing Office), p. 673-797.

Schulz, P., 1928. Beiträge zur Kenntnis fossiler und rezenter Silicoflagellaten: Bot. Archiv, v. 21, p. 225-292.

Stradner, H., 1961. Über fossile Silicoflagelliden und die Möglichkeit ihrer Verwendung in der Erdölstratigraphie: Erdöl Kohle, v. 14, p. 87-92.

Tsumura, K., 1963. A systematic study of Silicoflagellatae: Yokohama Municipal Univ. J., ser. C-45, no. 146, p. 1-84.

Worsley, T. R. and Jorgens, M. L., 1974. Oligocene calcareous nannofossil provinces: Soc. Econ. Paleontol. Mineral. Spec. Pub., no. 21, p. 85-108. 


\section{PLATE 1}

Silicoflagellates From DSDP Leg 43

Figures 1, 2, 5-18 magnified 800x; scale bar equals $10 \mu \mathrm{m}$.

Figures 3, 4 magnified $450 \times$; scale bar equals $10 \mu \mathrm{m}$.

Figures 1, 2 Corbisema bimucronata bimucronata Deflandre.

1. Sample 385-6, CC (156 m).

2. Sample $385-4-3,130-132 \mathrm{~cm}(140 \mathrm{~m})$.

Figures 3, 4 Corbisema disymmetrica communis Bukry.

3. Sample 384-6-2, 47-49 cm (101 m).

4. Sample $385-4-3,130-132 \mathrm{~cm}(140 \mathrm{~m})$.

Figures 5, 6 Corbisema hastata hastata (Lemmermann).

5. Sample 384-6, CC (105 m).

6. Spineless, Sample $384-7-1,105-106 \mathrm{~cm}$ (109 $\mathrm{m})$.

Figure $7 \quad$ Corbisema inermis minor (Glezer). Sample 384-6-4, 100-101 cm (104 m).

Figure $8 \quad$ Corbisema triacantha triacantha (Ehrenberg). Sample 385-4-2, 80-82 cm (138 m).

Figure $9 \quad$ Cornua trifurcata Schulz.

Sample 385-2-6, 80-82 cm (69 m).

Figure $10 \quad$ Dictyocha sp. aff. D. brevispina (Lemmermann). Sample 385-4-3, 130-132 cm (140 m).

Figures 11-17 Dictyocha deflandrei lobata $\mathrm{n}$. subsp.

11. USNM 242671, Sample 384-4-2, 80-82 cm $(138 \mathrm{~m})$

12. USNM 242672, Sample 385-6, CC (156 m).

13. Holotype, USNM 242670, Sample 385-4-3, $130-132 \mathrm{~cm}(140 \mathrm{~m})$.

14. USNM 242673, Sample 385-4-3, 130-132 cm $(140 \mathrm{~m})$.

15. USNM 242674, Sample $385-4-2,80-82 \mathrm{~cm}$ $(138 \mathrm{~m})$.

16. USNM 242675, Sample 385-6, CC (156 m).

17. USNM 242676, Sample 385-4-2, $80-82 \mathrm{~cm}$ (138 m).

Figure $18 \quad$ Dictyocha elongata Glezer.

Surrounded by coccoliths and two star-shaped Discoaster mohleri Bukry and Percival; Sample 384-7-3, 100-101 cm (112 m). 
PLATE 1

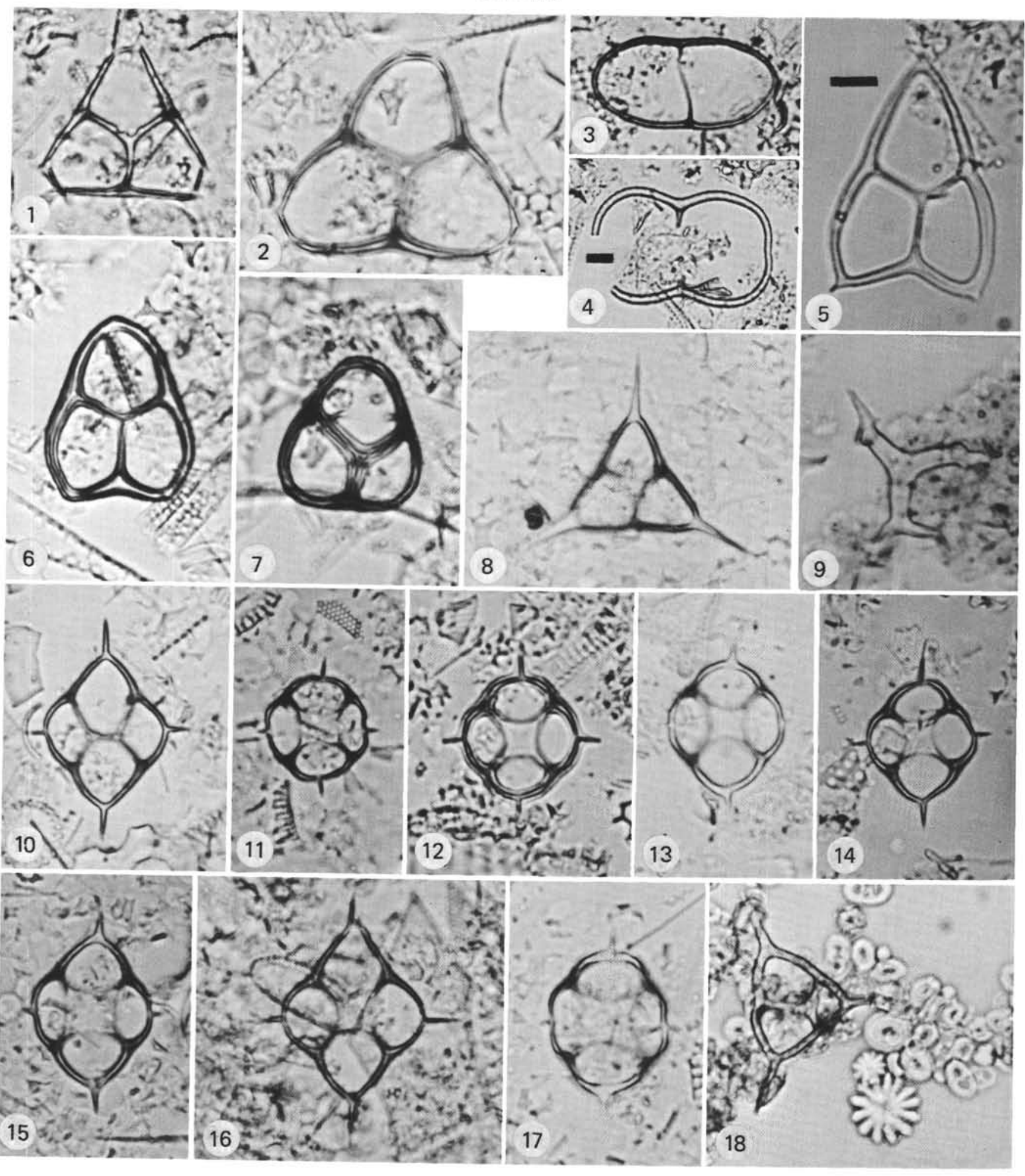




\section{PLATE 2}

Silicoflagellates From DSDP Leg 43

Figures 1-11, 13-19 magnified 800×; scale bar equals $10 \mu \mathrm{m}$. Figure 12 magnified $450 \times$; scale bar equals $10 \mu \mathrm{m}$.

Figures 1-3 Dictyocha elongata Glezer.

1. Sample 384-7-1, 105-106 cm (109 m).

2. Sample $384-7-3,100-101 \mathrm{~cm}(112 \mathrm{~m})$.

3. Sample $384-6-4,100-101 \mathrm{~cm}(104 \mathrm{~m})$.

Figures 4, 5 Dictyocha sp. A.

High and low focuses; Sample 386-14-5, 134-135 $\mathrm{cm}(335 \mathrm{~m})$.

Figure $6 \quad$ Dictyocha sp. (asperoid).

Sample 384-6-1, 100-101 cm (100 m).

Figure $7 \quad$ Dictyocha $\mathrm{sp}$. (deflandroid).

Sample 384-6-2, 47-49 cm (101 m).

Figures 8, 9 Distephanus crux crux (Ehrenberg).

8. Sample 385-2-6, 80-82 cm (69 m).

9. Sample $385-2-3,90-91 \mathrm{~cm}(64 \mathrm{~m})$.

Figure 10 Distephanus polyactis (Ehrenberg) s. ampl. Sample 386-17-1, 88-89 cm (386 m).

Figure 11 Distephanus speculum pentagonus Lemmermann s. ampl.

Sample 385-6, CC (156 m).

Figure 12 Distephanus speculum quintus (Bukry and Foster). Sample 386-14-5, 134-135 cm (335 m).

Figures 13, 14 Distephanus speculum speculum (Ehrenberg).

13. Sample $385-2-3,90-91 \mathrm{~cm}(64 \mathrm{~m})$.

14. Sample $385-2-6,80-82 \mathrm{~cm}(69 \mathrm{~m})$.

Figure 15 Distephanus raupii Bukry.

Sample 385-2-3, 90-91 cm (64 m).

Figures 16-18 Lyramula furcula Hanna.

16. Sample 385-2-6, 80-82 cm (69 m).

17. Sample 385-3-3, 60-61 cm (102 m).

18. Sample $385-2-3,90-91 \mathrm{~cm}(64 \mathrm{~m})$.

Figure 19 Mesocena apiculata apiculata (Schulz).

Sample 385-3-3, 60-61 cm (102 m). 
PLATE 2

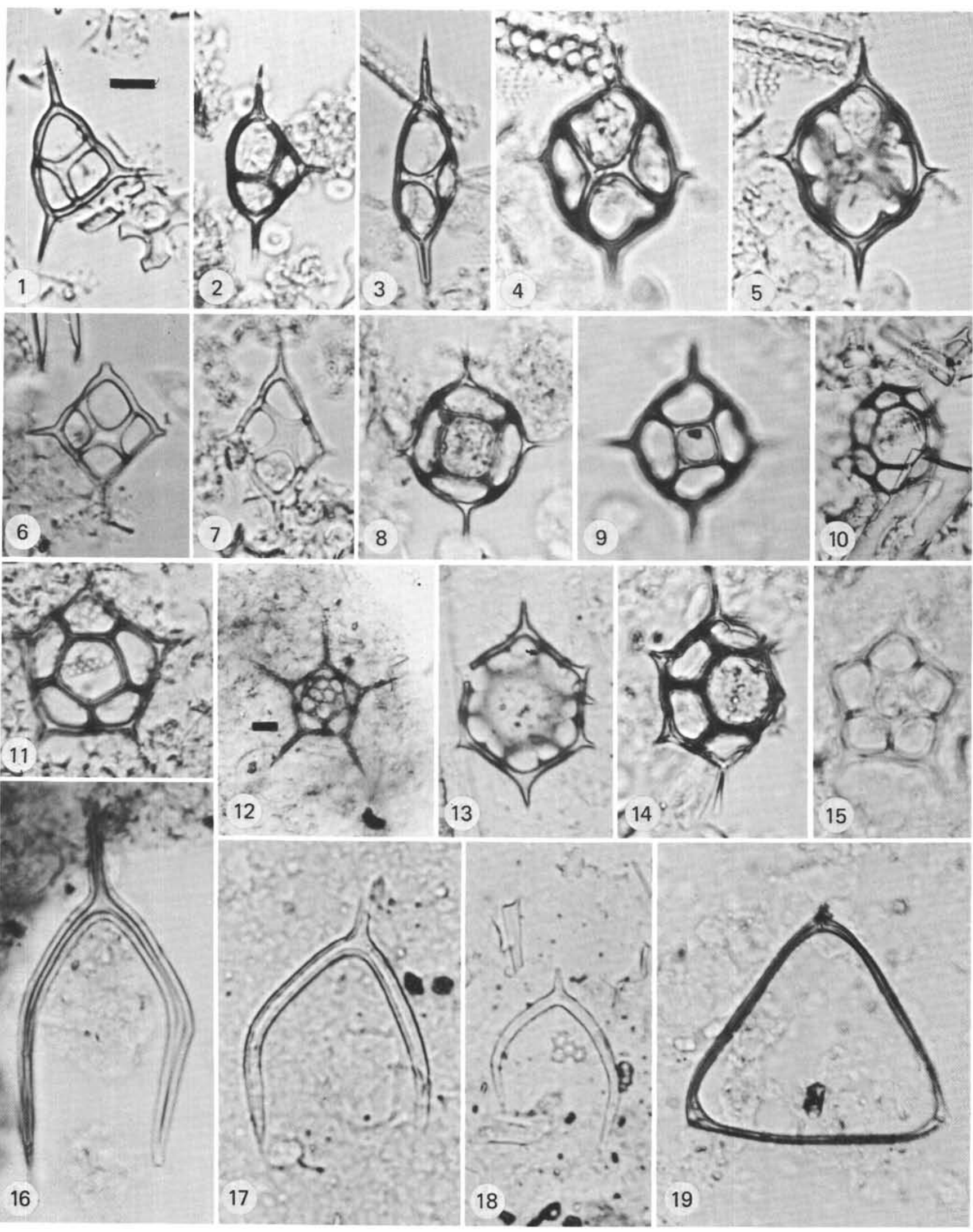




\section{PLATE 3}

Silicoflagellates From DSDP Leg 43

Figures 1-6, 11, 12, 15 magnified $800 \times$; scale bar equals $10 \mu \mathrm{m}$. Figures 7-10, 13, 14 magnified 450x; scale bar equals $10 \mu \mathrm{m}$.

Figures 1-3 Mesocena apiculata inflata $\mathrm{n}$. subsp.

1. USNM 242678, Sample 385-6, CC (156 m).

2. USNM 242679, Sample 385-4-2, 80-82 cm $(138 \mathrm{~m})$.

3. Holotype, USNM 242677, Sample 385-6, CC $(156 \mathrm{~m})$.

Figures 4, $5 \quad$ Mesocena? connudata $\mathrm{n}$. sp.

4. Holotype, USNM 242680, Sample 384-6-3, $100-101 \mathrm{~cm}(103 \mathrm{~m})$.

5. USNM 242681, Sample 384-7-1, 105-106 cm (109 m).

Figure $6 \quad$ Mesocena ovata n. sp.

Holotype, USNM 242682, Sample 384-7-1, 105 $106 \mathrm{~cm}(109 \mathrm{~m})$.

Figures 7, $8 \quad$ Mesocena venusta Bukry.

7. Sample 386-15-3, 100-101 cm (351 m).

8. Sample 386-14-5, 134-135 cm (335 m).

Figures 9, 10 Naviculopsis biapiculata (Lemmermann).

High and low focuses; Sample 385-3-6, 78-80 cm $(107 \mathrm{~m})$.

Figures 11, 12 Naviculopsis constricta (Schulz).

Deformed and normal forms; Sample 384-6-1, $100-101 \mathrm{~cm}(100 \mathrm{~m})$.

Figures 13, 14 Naviculopsis sp. cf. N. constricta (Schulz). Sample 384-7-3, 100-101 cm (112 m).

Figure 15 Naviculopsis danica Perch-Nielsen. Sample 384-7-2, 110-111 cm (110 m). 
PLATE 3
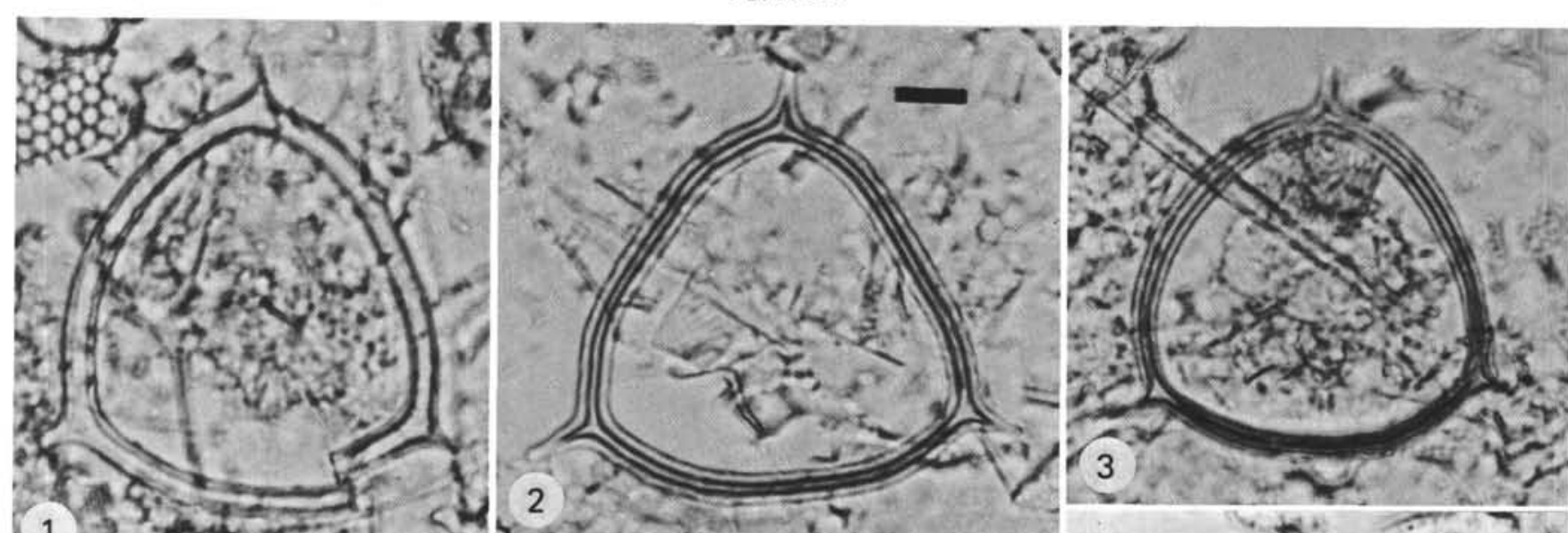

1 ingenif sol
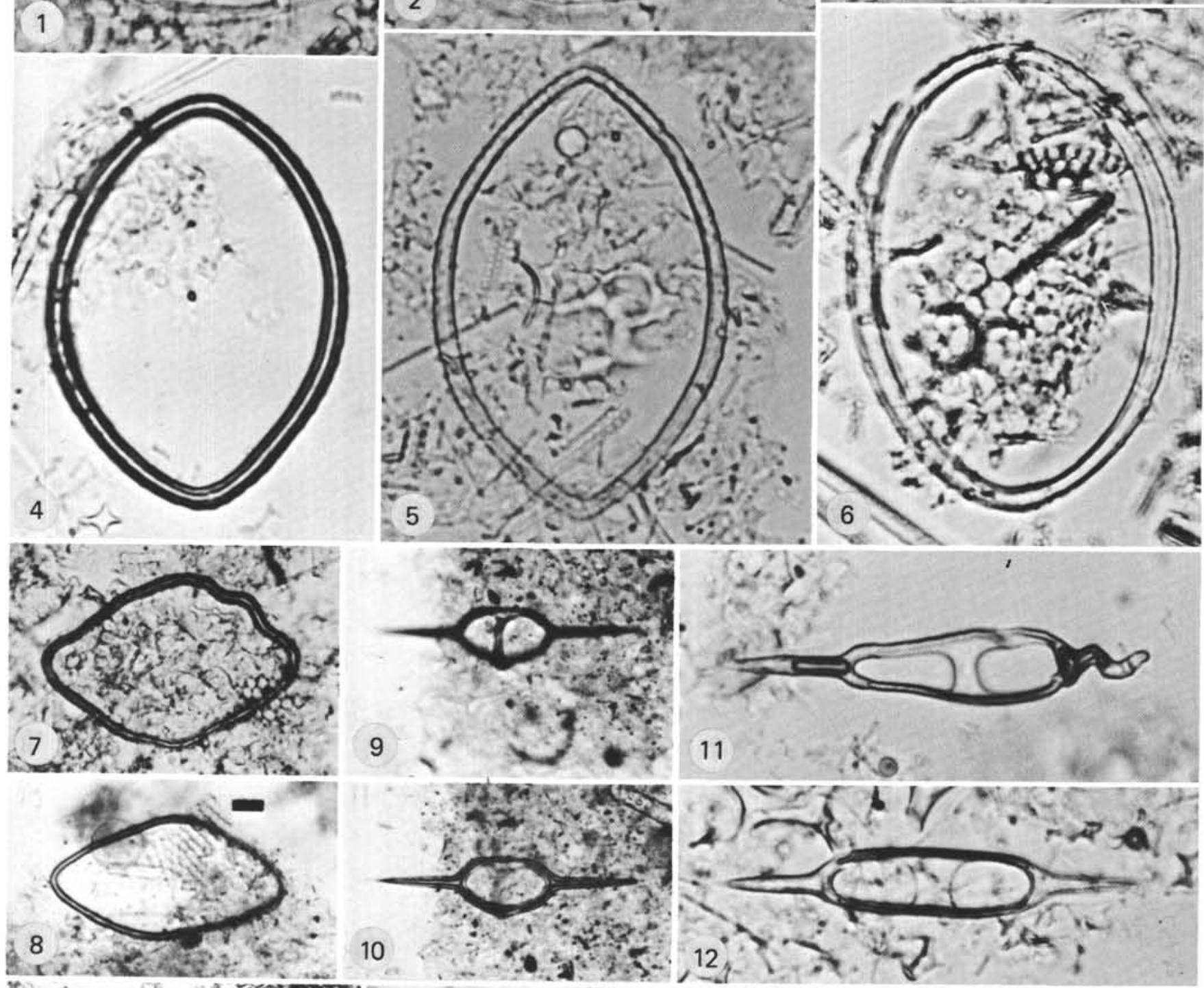

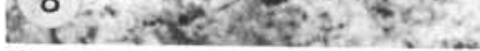

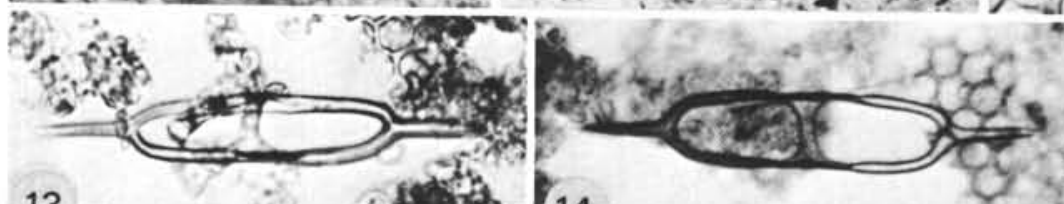

$13 \mathrm{D}$ (a) का

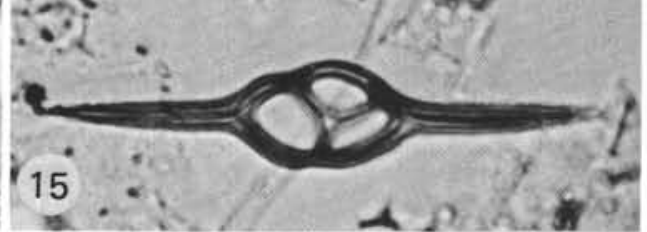




\section{PLATE 4}

Silicoflagellates From DSDP Leg 43

Figures 1-8, 13-16, 18-24 magnified $800 \times$; scale bar equals 10 $\mu \mathrm{m}$.

Figures 9-12, 17 magnified 450x; scale bar equals $10 \mu \mathrm{m}$.

Figures 1-8 Naviculopsis danica Perch-Nielsen.

1. Sample $384-6-2,47-49 \mathrm{~cm}(100 \mathrm{~m})$.

2. Sample $384-6-2,47-49 \mathrm{~cm}(100 \mathrm{~m})$.

3. Sample 384-6-4, 100-101 cm (104 m).

4. Sample 384-6, CC (105 m).

5. Oblique view, Sample 384-6-4, 100-101 cm (104 m).

6. Variant, Sample 384-6-2, 103-104 cm (101 m).

7. Variant, Sample 384-6, CC $(105 \mathrm{~m})$.

8. Paired skeletons, Sample 384-6, CC (105 m).

Figures 9-16 Naviculopsis eobiapiculata n. sp.

9. Holotype, USNM 242683, Sample 385-4-3, $130-132 \mathrm{~cm}(140 \mathrm{~m})$.

10. USNM 242684, Sample 385-6, CC (156 m).

11. USNM 242685, Sample 385-6, CC (156 m).

12. USNM 242686, Sample 385-4-3, 130-132 cm (140 m).

13. USNM 242687, Sample 385-2-3, $90-91 \mathrm{~cm}$ (64 m).

14. USNM 242688, Sample $385-2-6,80-82 \mathrm{~cm}$ (69 m).

15. USNM 242689, Sample $385-2-6,80-82 \mathrm{~cm}$ (69 m).

16. USNM 242690, Sample 385-3-3, 60-61 $\mathrm{cm} \quad(102 \mathrm{~m})$.

Figure 17 Naviculopsis sp. cf. N. eobiapiculata n. sp.

Sample 384-6-1, 100-101 cm (100 m).

Figures 18, 19 Macrora barbadensis (Deflandre).

Sample 386-14-5, 134-135 cm (335 m).

Figures 20, 21 Macrora stella (Azpeitia).

Low and high focuses, Sample 385-2-6, $80-82 \mathrm{~cm}$ (69 m).

Figures 22-24 Corbisema sp. cf. C. hastata hastata (Lemmermann) [paired spines].

22. Sample 384-7-1, $105-106 \mathrm{~cm}(109 \mathrm{~m})$.

23. Sample 384-7-3, 100-101 cm (112 m).

24. Sample 384-6-2, 103-104 cm (101 m). 
PLATE 4
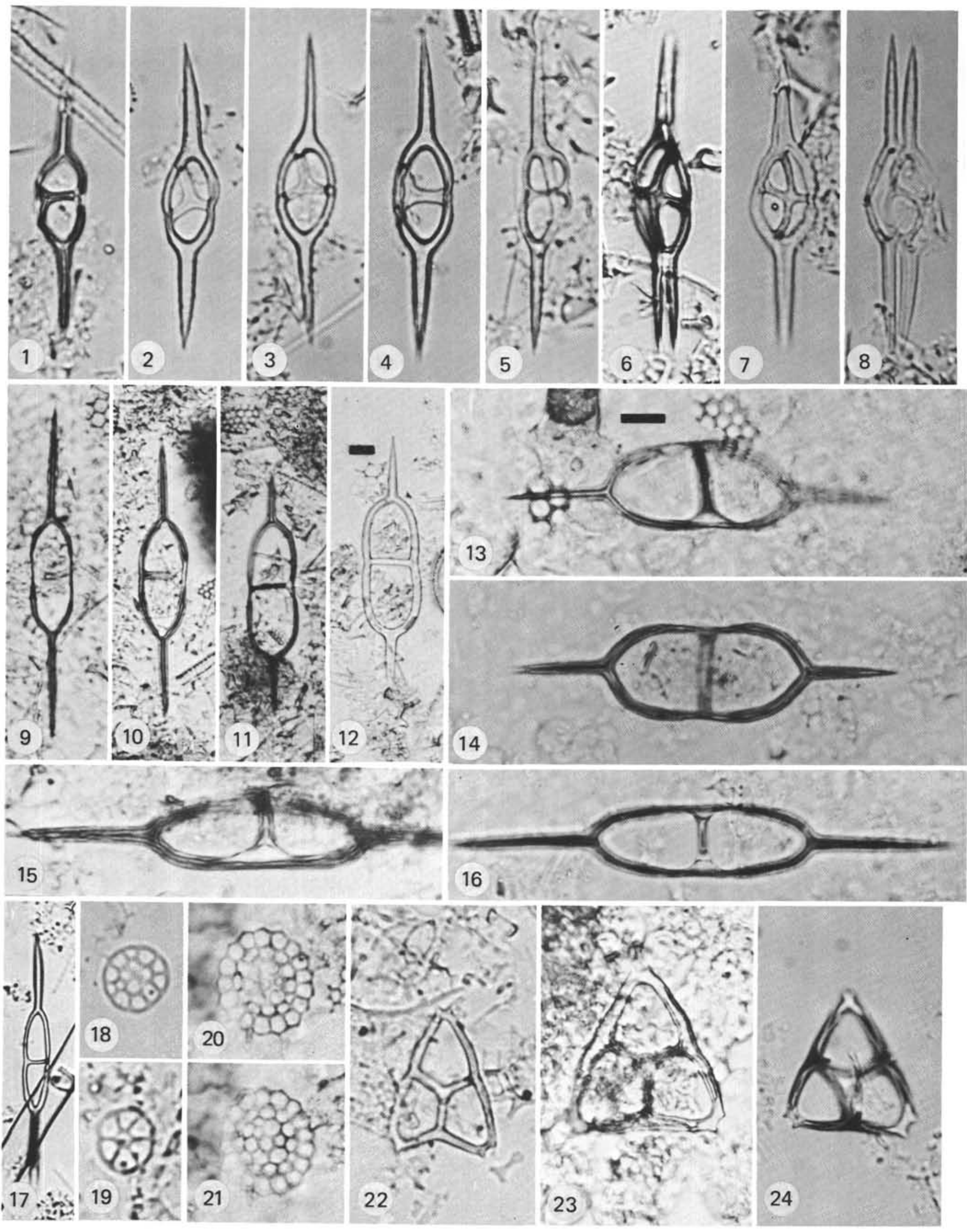


\section{PLATE 5}

\section{Specimens of Rocella gelida (Mann) From DSDP Leg 43}

Unless noted otherwise, specimens are from Sample 385-2-6, $80-82 \mathrm{~cm}(69 \mathrm{~m})$. Figures $1-8,11-13$, scale bar equals $10 \mu \mathrm{m}$.

Figures 9,10 , scale bar equals $20 \mu \mathrm{m}$.

Figures 1-3 Double skeleton, through focal series.

Figure $4 \quad$ Double skeleton.

Figure 5 Dissolution fragment, Sample 385-3-3, 60-61 cm (102 m).

Figures 6-11 Slightly etched whole valves.

7. Sample $385-2-3,90-91 \mathrm{~cm}(64 \mathrm{~m})$.

Figure 12 Dissolution fragment; central area is most resistant; Sample 385-2-3, 90-91 cm (64 m).

Figure 13 Dissolution fragment; central-area bar and perforation are the last identifiable remnant, Sample 385-3-6, 78-80 cm (107 m). 
PLATE 5

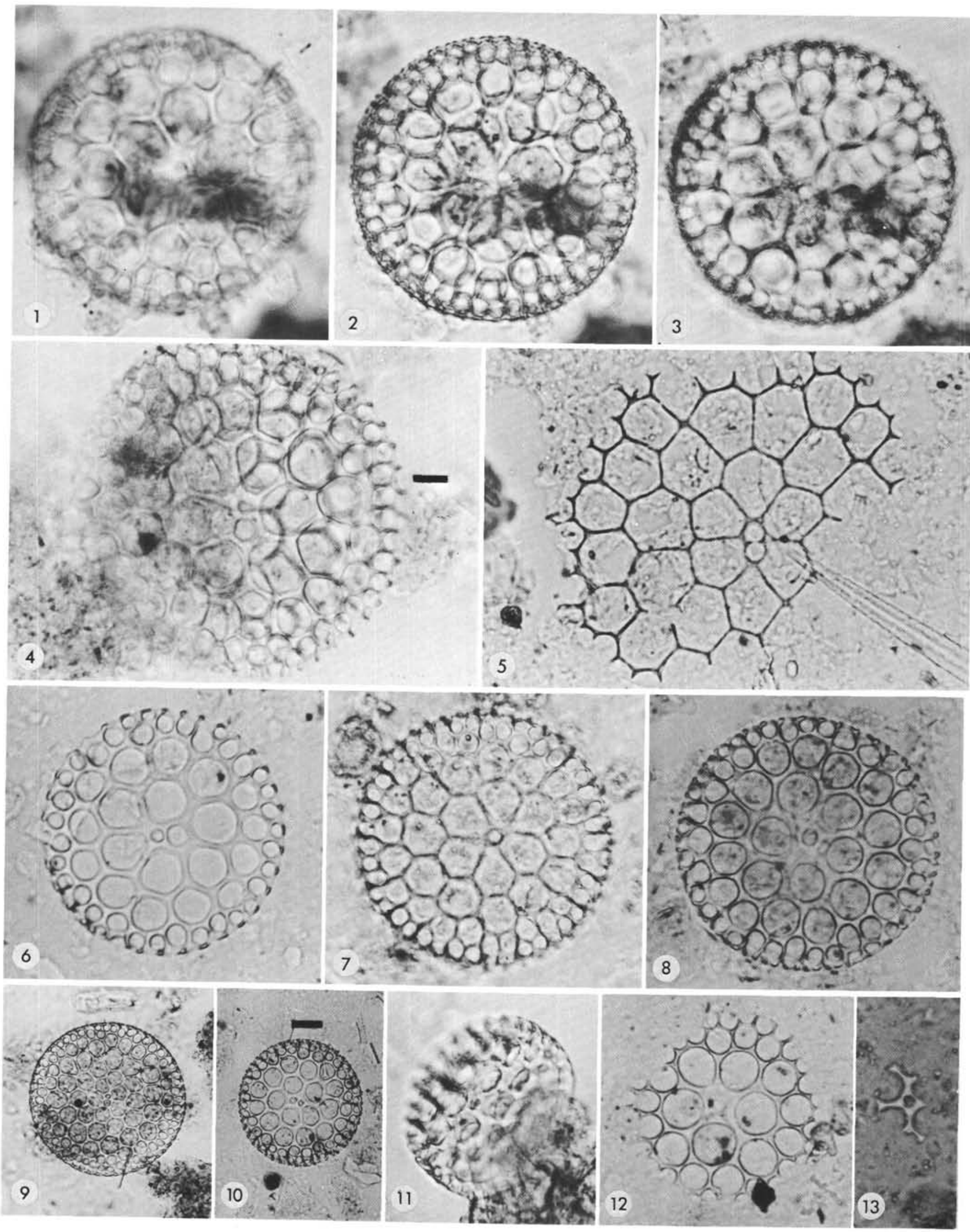




\section{PLATE 6}

Specimens of Rocella schraderi $\mathrm{n}$. sp.

\section{From DSDP Leg 43 and Scripps Core JYN V16.}

Figures 1-6, scale bar equals $10 \mu \mathrm{m}$;

Figure 7, scale bar equals $20 \mu \mathrm{m}$;

Figures 8-10, scale bar equals $10 \mu \mathrm{m}$.

Figure 1 USNM 242692, Sample 385-2-6, 80-82 cm (69 m).

Figures 2, 3 Low and high focuses, USNM 242693, Sample $385-2-6,80-82 \mathrm{~cm}(69 \mathrm{~m})$.

Figure 4 USNM 242694, Sample 385-2-6, 80-82 cm (69 m).

Figures 5, 6 Low and high focuses, Holotype, USNM 242691, Sample 385-2-3, 90-91 cm (64 m).

Figure 7 USNM 242695, Sample 385-2-6, 80-82 cm (69 m).

Figures 8-10 Scanning electronmicrographs of figured specimens from Scripps, Sample JYN V 16P, 153-156 cm (lat $7^{\circ} 44^{\prime} \mathrm{N}$, long $149^{\circ} 44^{\prime} \mathrm{W}$, water depth 5168 m), provided by J. A. Barron, U.S. Geological Survey. 
PLATE 6

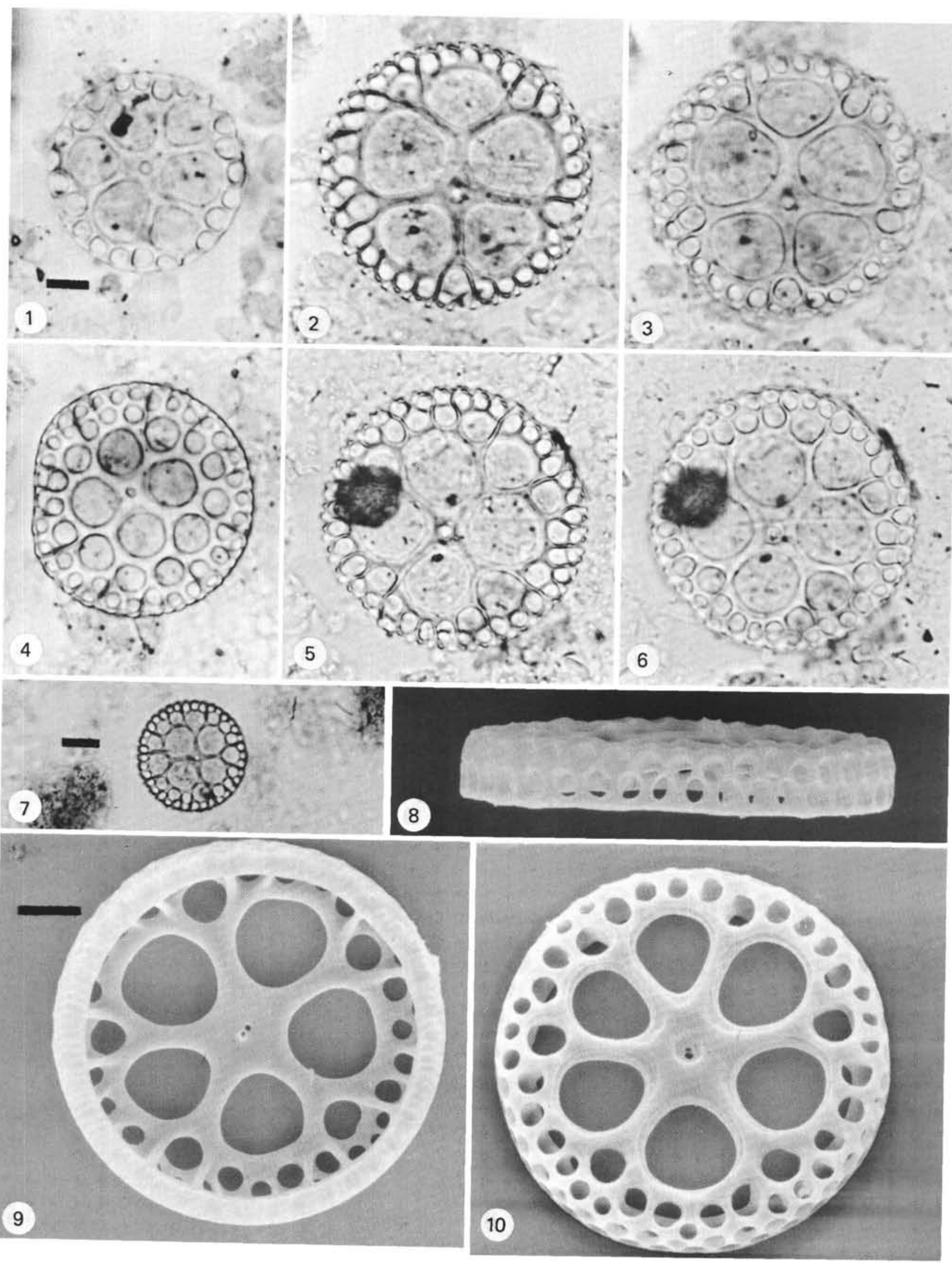




\section{PLATE 7}

\section{Rocella schraderi and Some Diatom Specimens} From DSDP Leg 43

Figures 1-5, 8, 10-12; scale bar equals $10 \mu \mathrm{m}$. Figures 6, 7, 9; scale bar equals $10 \mu \mathrm{m}$.

Figure $1 \quad$ Rocella schraderi $\mathrm{n}$. sp. USNM 242696, Sample 385-2-6, 80-82 cm (69 m).

Figure 2 Actinocyclus lanceolatus (Castracane). Sample $385-2-6,80-82 \mathrm{~cm}(69 \mathrm{~m})$.

Figure 3. Cussia sp. cf. C. paleaceus (Grunow). Sample 385-2-6, 80-82 cm (69 m).

Figures 4, 5 Asteromphalus sp.

Sample 386-14-5, 134-135 cm (335 m).

4. Upper valve focused.

5. Lower valve focused, same specimen.

Figures 6, 7 Goniothecium decoratum Brun. Sample 385-2-6, $80-82 \mathrm{~cm}(69 \mathrm{~m})$.

6. Top view.

7. Side view.

Figure 8 Diatom sp. A. Sample 385-4-3, 130-132 cm (140 $\mathrm{m})$.

Figure $9 \quad$ Aulacodiscus sp.

Sample 385-2-6, 80-82 cm (69 m).

Figure 10 Coscinodiscus vigilans Schmidt.

Sample 385-2-6, 80-82 cm (69 m).

Figures 11, 12 Coscinodiscus? sp.

Distinctive morphologic and stratigraphic species with large central areola from the middle Eocene at Sites 385 and 386. Occurs in lower Eocene at Site 390A.

11. Sample $385-4-3,130-132 \mathrm{~cm}(140 \mathrm{~m})$.

12. Sample $385-6$, CC (156 m). 


\section{PLATE 7}

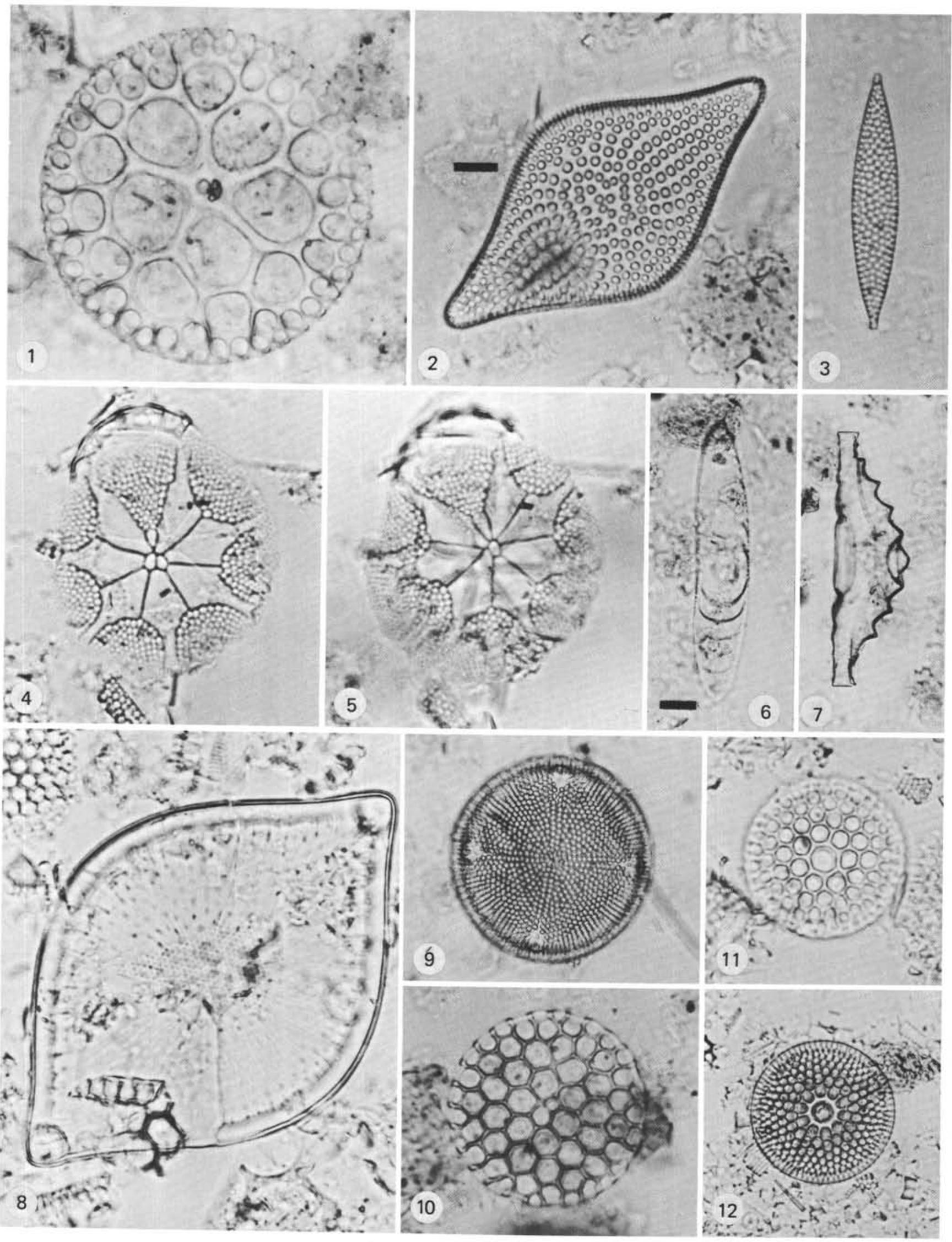

